Araştırma Makalesi

\title{
İletişim Becerilerini İnşa Eden Faktörlerle İlgili İletişim Fakültesi Öğrencileri Üzerine Karşılaştırmalı Bir Analiz
}

\author{
Hamza Çakır (Prof. Dr.) \\ Erciyes Üniversitesi İletişim Fakültesi \\ hcakir@erciyes.edu.tr \\ Orcid: 0000-0002-4548-5772 \\ Uğur Ünal (Dr. Öğr. Üyesi) \\ Kırgızistan-Türkiye Manas Üniversitesi İletişim Fakültesi \\ unalugur09@gmail.com \\ Orcid: 0000-0003-0294-0082
}

Başvuru Tarihi: 02.05.2019

Yayına Kabul Tarihi: 15.05.2019

Yayınlanma Tarihi: 22.07.2019

DOI: 10.17680/erciyesiletisim.559907

\begin{abstract}
Çakır, H. ve Ünal, U. (2019). İletişim Becerilerini İnşa Eden Faktörlerle İlgili İletişim Fakültesi Öğrencileri Üzerine Karșılaștırmalı Bir Analiz. Erciyes İletișim Dergisi, 6 (2), 929-954. DOI: 10.17680/erciyesiletisim.559907
\end{abstract}

\section{Öz}

Doğal ve kaçınılmaz bir sosyal gereksinim olarak iletişim, insanın varlık durumudur. İnsanın kendisini, çevresini, ait olduğu toplumu ve dünyayı anlamlandırma aracıdır. Dolayısıyla, insanın yaşam dünyası açısından bu anlamlandırmanın önemi tartışılmazdır. Bu bağlamdaki değerlendirmelerde, insan ilişkilerinde karşılaşılan pek çok anlaşmazlığın altında iletişim kurmadaki yetkinsizliğin yattığı anlaşılmaktadır. Dolayısıyla genel olarak bu anlaşmazlıkların kaynaklık ettiği psikolojik problemlerin altında yatan başat etkenler olarak da iletişimdeki yetkinsizlikleri ya da iletişim becerilerindeki eksiklikleri görmek gerekmektedir. Bireylerde iletişim becerilerinin oluşmasında birçok faktörün etkisi söz konusudur. Kişisel özelliklerinin yanı sıra yapılan bilimsel çalışmalar bireylerin empatik eğilimleri ile iletişim becerilerinin oluşmasında pozitif yönlü bir ilişkinin olduğunu göstermektedir.

Söz konusu bu çalışmanın da Kırgızistan-Türkiye Manas Üniversitesi ile Erciyes Üniversitesi İletişim Fakültelerinde eğitim gören öğrencilerin iletişim kurmadaki becerileri ve empatik tepki düzeyleri ortaya konularak, öğrencilerin gerek kişisel özellikleri gerek ise empati yatkınlıkları ile sosyal etkileşimdeki becerileri arasında nasıl bir ilişkinin olduğunu araștırmak başlıca amacını oluşturmaktadır. Niceliksel yöntemle yürütülen araștırma için İletişim Fakültelerinde eğitim alıyor olmak bu değişkenler arasındaki ilişkiyi nasıl etkilemektedir sorgulaması önem taşımaktadır. Nicel testlere tabi tutulan katılımcı değerlendirmeleri sonrasında empatik eğilim arttıkça iletişim becerileri de yükseltmektedir genel sonucuna ulaşılmıştır. Araştırmadaki karşılaştırmalı testlerin sonuçları da alanyazındaki diğer araştırma sonuçları ile pozitif yönlü bir ilişkisellik sunmuştur.

Anahtar Kelimeler: İletişim, İletişim Becerileri, Empatik Eğilim, Yükseköğrenim. 


\title{
A Comparative Analysis on the Factors Building Communication Skills of Students Who Study at the Faculty of Communication
}

\author{
Hamza Çakır (Prof. Dr.) \\ Erciyes University Faculty of Communication \\ hcakir@erciyes.edu.tr \\ Orcid: 0000-0002-4548-5772 \\ Uğur Ünal (Asst. Prof. Dr.) \\ Kyrgyz-Turkish Manas University Faculty of Communication \\ unalugur09@gmail.com \\ Orcid: 0000-0003-0294-0082
}

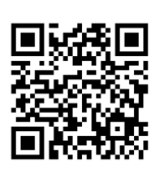

Date Received: 02.05.2019

Date Accepted: 15.05.2019

Date Published: 22.07.2019

DOI: 10.17680/erciyesiletisim.559907

\section{Abstract}

In human life communication is as also important as feeding. Effective communication is essential to understand ourselves, our environment and the society we belong to. The reasons of the problems in interpersonal relations and the many psychological disorders that arise due to these problems come from communication skills. There are many factors affecting communication skills of individuals. Scientific studies show that there is a positive relationship between individuals' personal characteristics and empathic tendencies and communication skills.

In this study, the communication skills and empathic tendency levels of the students studying at communication faculties of Kyrgyz-Turkish Manas University and Erciyes University were determined. Also it is aimed to reveal the relationship between personal characteristics and empathic tendencies of students and their communication skills. In quantitative research, it is important to question how to be educated in communication faculties affects the relationship between these variables. After quantitative tests it was found that when the empathic tendency increases, communication skills are also increased. The results of the comparative tests showed a positive correlation with the other research results.

Keywords: Communication, Communication Skills, Empathic Tendency, Higher Education. 


\section{Giriş}

\section{İnsanın Toplumsallığı}

Her toplumu oluşturan kültürel yapı kendiliği içinde örf, adet, gelenek ve göreneklerinin yanı sıra ahlak, sanat ve inanç dünyası ile harmanlanan bir bilgi dağarcığını barındırmaktadır. Sosyalleșme söz konusu kültürü kazanım yoludur. $\mathrm{Bu}$ durum insanlar arasında iletişimi zorunlu kılar, sosyalleşmenin sağlanması sosyal etkileşime tabidir çünkü. Bir başka ifadeyle, iletişim toplumsal varlığın başat koşuludur, sina qua non durumudur (Atabek ve Dağdaş, 1998, 283). İnsanı değiștiren bir süreç olarak iletişim kültürel (hem doğal hem toplumsal çevresi) çevreye göre de değişim yaşayan bir olgudur (Zıllığlu, 1993, 94). Dolayısıyla, iletişimden söz etmek bir anlamda kültürden söz etmek anlamına gelir.

Süreçsel yapısı gereği iletişim içinde birbirini takip eden eylemsellik yaşanır. Silsile şeklinde gerçekleşen eylemler dizisi içinde karşılıklı ilişkiler gerçekleşir ve söz konusu bu ilişkiler her zaman değişime tabidir. Sosyal etkileşim bu nedenle sürekli bir çaba gerektirir, kaçınılmaz şekilde tekrarlanamayan ilişkiler kapsayabilmektedir. Dolayısıyla, iletişimde aktif aktörel yapı karşılıklı ilişkiler ile belirginlik kazanır. Bu kazanımı sağlayan da insanların tutum ve becerilerinin altındaki deneyimleri ve bu deneyimleri ortaya çıkaran sosyal çevreler olmaktadır. (Erdoğan, 2002, 33).

$\mathrm{Bu}$ süreçsel gerçekleşimin insan hayatı için önemi tartışılmaz konumdadır, bu nedenle kaynak ve hedef, bir başka ifadeyle konuşucu ve dinleyici arasındaki virtüel/dönüşümlü rolün sağlıklı işleyebilmesi için mesajın aslına uygun şekilde aktarılması oldukça büyük önem taşımaktadır. İşte, bu şekilde bir iletişimsel eylemliliğin bir süreç içinde gerçekleștiği görülmektedir, ancak bu sürecin devamlı ve sürekli değișen bir yapıya sahip olduğu dikkate alınması gereken en temel olgusallığı oluşturmaktadır (Demiray, 1994, 34). Ki, bu anlamda iletişim bir süreçtir ve sürekli değişim halindedir.

Toplumsal düzenlerin zaman ve uzamı ilişkilendirmeyi nasıl gerçekleștirdiği sorunu da yine iletişim algısı ile ilintili görülmektedir. Burada düzen sorunu, zaman/uzam uzaklaşmasıyla, bir diğer söyleyişle zaman ve uzamın varlık ve yokluk olgularını birleştirecek biçimde düzenlendiği koşullarla ilgili olarak belirir. Zıllıoğlu'nun da belirttiği gibi, toplumsallığı ortaya koyan anlam aktarımıdır, bu da ancak iletişim ile var olabilir. Dolayısıyla, insanın anlam oluşturma edimi ya da iletişim yetkinliği ile bilgi ve deneyim paylaşılabilmekte ve de kuşaktan kuşağa aktarılarak 'toplumsallı' görünüm kazanabilmektedir. Böylelikle de anlam zamanda ve mekânda korunabilmektedir (Zıllıoğlu, 1993, 13). Habermasyen bakıș açısına göre de, insan yaşam dünyası içinde oldukça farklı uyarılara maruz kalmaktadır ve bu aynı zamanda süreklilik de arz etmektedir. Buna yol açan temel etkenin de yapının komplike halinin karmaşık nitelik taşımasıdır denilebilir.

Karşılıklı ilişkiler çerçevesinde söz konusu olan uyarıların içeriksel anlamlılı̆̆ı yaşam dünyamızı o kadar olumlu etkiler. Yaşadığımız toplumsal çevrenin iyi, güzel, yaşamaya değer olması iletilerin anlamlılığına koşutluk gösterir. Hiç şüphesiz, toplumsal çevre, yaşam deneyimleri, çevre algısı ve yorumlanması söz konusu koşutluğun gerçekleşmesinde rol oynar.

Etki bireyi geliştiren başat unsurdur. Gerçekleşme ortamı da toplumdur, toplumsallık bireyselliğin belirleyicisi konumundadır (İsen ve Batmaz, 2002, 166). 
Ebeveynlerinin çeşitli özellikleri doğduğu andan itibaren insana geçmeye başlar. Kuşaklar boyu devam eden bu aktarımın tarihsel gelişimi vardır. Psikoloji alan yazınının aktarımına göre, içinde yaşanılan toplumun kalıtım öğeleri üzerindeki etkisinin önemi tartışmasız kabul edilmektedir (İsen ve Batmaz, 2002, 167).

İnsanın diğer insanlarla iletişiminde sürece etki eden önemli başat unsurların başında bireysel biliş ve dilsel yetkinlik gelmektedir. Bilindiği üzere, karşllıklı etkileşime dayalı iletişim sürecinde kaynak ve hedef olarak konuşucu ve dinleyicinin toplumsal karakteri belirleyici olmaktadır. Kullanılan dilsel söylem, kavramsal içerik, anlamsal bütünlük toplumsal etkileşimin ne şekilde ilerleyeceği konusunda başat rol oynamaktadır (Hummet, Wiemann ve Nussbaum, 1994, 5). Buradan yola çıkarak, iletişimin kaçınılmaz olarak, de facto şekilde bir anlamlandırma çabası olduğu anlaşılabilir. Öyle ki, anlam yükleme toplumsallığın temel çıktısı olmakla birlikte, toplumsalın devamını, kendini yeniden oluşturmasını sağlamaktadır (Oskay, 1994, 8).

Oskay'ın da belirttiği gibi, fiziksel ve toplumsal olarak insanın var oluşunun temel koşulu iletişimdir (Oskay, 1994, 504). Tabii hak'ka dayalı gelişmiş olan doğal hukuk fiksiyonunun ortaya koyduğu gibi var olması ile birlikte insanın toplum yaşantısı içinde elde ettiği belli hak, özgürlük ve amaçları vardır. Elbette ki en temel amaç insanın hayatta kalması ve yaşamını devam ettirebilmesidir. İşte insan bu doğal devinimlerini gerçekleştirmek için de hiç şüphesiz iletişime gereksinim duymaktadır. Toplumsal yapı örgütlü bir yapıdır, dolayısıyla normatif bir eksene dayalı olarak devingenlik göstermektedir. Bu devingenlik içinde toplumsal gerçekliğini sağlayan insan, gerek yazılı gerekse de sözlü kültürün imge ve sembolleri ile varlığını anlamlandırmaktadır. Bu nedenle hayatının her aşaması iletişimle gerçekleşmekte, toplumsal olarak gelişim ve değişimi, yaşanan koşullara uyum yeteneği toplumsal varlığını sürdürmesinde etken olan iletişimle sağlanabilmektedir.

İfade etmek gerekirse, toplumsal düzeni bütünleștiren benzerlik değil, farklılıktır. Ancak, kişi baskı duygusunu nasıl açıklarsa açıklasın, duygunun kökenleri her zaman kişinin kendi amaçları ve amaçlarına göre hareket etme olasılığı arasındaki çatışmada yatar. İşlevsel açıdan bölünmüş çağcıl toplumda, bireyin yalnızca yakın iliş̧ide bulunduğu kişilerden alabileceği 'dost sıcaklığı'na her zamankinden daha çok gereksinim duyduğunu söylemeye gerek yoktur. $\mathrm{Bu}$ nedenle, özgürlük ve toplumsal etkileşim gereksinimi, daha çok çatışma halinde olsalar da birbirlerinden ayrılmazlar (Duverger, 1971, 189) Bu insanlık durumunun kalıcı özelliği gibidir.

$\mathrm{Bu}$ çerçevede çalışmanın başlıca amacını, Kırgızistan-Türkiye Manas Üniversitesi ile Erciyes Üniversitesi İletişim Fakültelerinde eğitim gören öğrencilerin iletişim kurmadaki becerileri ve empatik tepki düzeyleri ortaya koyularak, öğrencilerin gerek kişisel özellikleri gerek ise empati yatkınlıkları ile sosyal etkileşimdeki becerileri arasında nasıl bir ilişkinin olduğunu araştırmak oluşturmaktadır.

\section{Sosyal Etkileşim}

İnsanın sosyal bir varlık olduğu Antikiteden bu yana keşfedilmiş bir gerçekliktir. Kendi kendine yeterliliği söz konusu değildir. Aslında bu durum sadece insana özgü değildir. Evrendeki tüm varlıklar için geçerlidir kendi kendine yetmezlik. Bu nedenle varlık ancak bir bütün içinde kendini bulur (İnam, 2003, 14). Bu bütünlüğü var kılan da iletişimdir, insan da çeşitli semboller aracılığıyla anlam aktarımı sağlayarak sosyal varlığını koruyabilmektedir. İşte insanın en temel gerçekliği budur, 'öteki/ leri'nin gerçekliği içinde kendi gerçekliğini kurmaktadır (Zıllıoğlu, 1993, 288). 
Gelişim psikolojisi genel olarak insanın gelişimini yakın çevresindeki insanların model olarak gözlemlenmesine bağlar. İnsanların karşılaştıkları farklı durumlarda nasıl davranış geliştirdikleri gözlenerek sosyal öğrenme gerçekleşmektedir ve bu öğrenme hayat boyu sürdürülen bir öğrenmedir. Bir anlamda sosyal etkileşimle keşfedilen bir öğrenme durumudur. Toplumsal normların ya da öğretilerin edinilmesi ile sosyal hayatımızı kurar, bu şekilde de yaşadığımız dünyaya da uyum sağlarız. Erken gelişim döneminde bu öğrenmenin başat aktörlerini aile başta olmak üzere birincil gruplar oluştururken, daha sonra bu süreçte ikincil gruplar olarak, arkadaşlar, öğretmenler, kanaat önderleri vb. etkili olmaya başlarlar. Bu şekilde rol modeller üzerinden yapılan keşiflerle öğrenilen kültür insanı toplumsallaştırır ve büyük bir uyum mekanizması da doğurur. Ortak anlamlar, kanılar, değerler vb. ile davranışlar sınanır. Ortak kabul görmüş sosyal normlar benimsenir, davranışları büyük oranda yansıtılır.

O nedenle insan yaşam dünyası içinde tavır ve davranışları için genellikle onay bekler. Özellikle örnek alınan insanlar tarafından onaylanmak ya da karşıtı büyük etki yaratır. Dolayısıyla insanın kimlik oluşumunda diğerleri ile etkileşimi büyük rol oynar. Kendiliğimiz ile ilgili algımız, bir başka ifadeyle benlik bilincimiz işte bu etkileşim sürecine dayalı olarak gelişim göstermektedir.

Kendimiz için oluşturduğumuz benlik algısını, kendimizle ilgili düşüncelerimizi şekillendiren başkalarının bizi algılayış biçimi olmaktadır. Diğer insanların davranışları bizi algılayış biçimleri hakkında en yetkin göstergeyi ortaya koymaya hizmet etmektedir. Kendimize verdiğimiz değer de benlik algımızdan anlaşıldığı için diğer insanların bize karşı davranışları 'kendiliğimiz' ile ilgili oldukça belirleyici olmaktadır. Bu durumda, başkalarıyla iletişim ve etkileşim içinde olmamız kişisel değerimizi, oluşturduğumuz kişisel imajı kaçınılmaz olarak etkilemektedir. $\mathrm{Bu}$ nedenle, sosyal etkileşim bireyin yaşam dünyasında en önemli ihtiyaçlarının başında yer almaktadır. Öyle ki, insanın kendisi ile ilgili bilgisi diye tarif edilen benlik algısının, bir başka ifadeyle belirtmek gerekirse benlik bilgisinin, öz saygısının inşaası bu etkileşim sayesinde gerçekleşmektedir.

İnsanın var oluşunda, kimlik ediniminde bu denli önem taşıyan sosyal etkileşim sayesinde başkalarının bizim ile ilgili duygu ve düşüncelerini öğrenmek olası olmaktadır. İnsanlardan geri bildirim alarak kendimiz ile ilgili bilgileri sınamak oldukça önemlidir. 1950 yılında iki Amerikalı psikolog Joseph Luft ve Harrington Ingham "Johari Window Modeli"ni geliştirerek, insanın sosyal ilişsilerinde kendisi ile ilgili aktarımda bulunduğu alanlarının yanı sıra paylaşımda bulunmadığı, bulunmak istemediği alanları da ortaya çıkarmışlardır (Luft, 1984, 11-20). Bu modelde iletişim sırasında insanların birbirleri hakkındaki bilgilerinin boyutları ortaya konulmaktadır. Dörtlü pencere şeklinde verilen alanlar açık, gizli, saklı ve bilinmeyen olmak üzere belirlenmiştir. Sağlıklı, tutarlı insan ilişkilerinde açık alanın geniş, diğerlerinin daha dar olduğu saptanmıştır. Bu durumun aksine açık alan dar iken gizli alanın daha geniş olması iletişimin gerçekliğini, samimiyetini, dolayısıyla etkililiğini bozan bir sonuca yol açmaktadır. Araştırmacılar iletişimi olumsuz etkileyen gizli yanımız ile kendimiz tarafından görülemeyen ancak başkalarının bizim hakkında bilgilerini oluşturan saklı ya da kör alanımızı da olabilecek en daraltılmış sınıra çekebilmek için 'empatik eğilim'in geliştirilmesi gerekliliğini önermektedirler. Empatik düşünebilen ve davranabilen, dolayısıyla empati becerisini geliştirmiş insanlar açık iletişim kurmaktadırlar. Açık iletişim karşılıklı 
bilgi düzeyinin yüksek derecede olduğunun göstergesi olduğu için empatik eğilimin de gerçekleşmesine olanak tanımaktadır.

Hangi davranışlar insanlarda hangi etkiyi bırakıyor sorusunu dikkate almak önemli bir tutumdur. İnsanlara ne gibi etkilerde bulunuyoruz, insanlar üzerindeki etkilerimiz ne şekildedir, olumlu ya da olumsuz söz konusu etkilerimizi öğrenebilmenin yolu çevremizdeki insanlara sorular sormaktan geçmektedir. Bu şekilde kendimizle ilgili çevre algısını öğrenmiş, aynı zamanda da değiştirmemiz gereken yanlarımızı açıkça fark etmiş oluruz. Kendimiz ile bilgimizin ve de öz saygımızın büyük kısmı bu sorulardan alacağımız yanıtlarla koşutluk göstereceği için, söz konusu bilgi edineceğimiz kişiler oldukça önem taşımaktadır. Bu nedenle kendiliğimiz ile ilgili geribildirimleri alacağımız insanları tartışmasız doğru seçmek gerekmektedir. En yalın ifadeyle, açı iletişimde bulunabilecek dürüstlükte insanlar olmasına dikkat etmeye özen gösterilmelidir. Sonuçta alınan geribildirimler tıpkı bir aynadaki suretin yansıması gibi - kendiliğin yansıması olarak zihinde işlev görecektir.

Aynı zamanda iletişim kurulan kişilerle ilgili belirsizlikleri gidermek amacıyla da bilgi edinme yoluna girilir. Belirsizlikler iletişimde istenmeyen durumlardır ve çözülemezlerse de pek çok sorunun nedeni olurlar. Etkileşim sayesinde bilgi edinerek mümkün mertebe herhangi bir durum karşısında sergilenecek davranışı tahmin edebilme olanağı yaratmak da amaçlar arasındadır. Bu nedenle öngörülemeyecek bir tutum ve davranışla karşılaşılmaktan kaçınılır, belirsizlikler ortadan kaldırılmaya çalışılır. Belirsizlikler azaldıkça da insanların birbirlerine güven duymaları artmaya başlar. Ancak her durumda bu şekilde bir sonuca ulaşılacağı ifade edilemez. İnsanlar birbirleri hakkında bilgi edindikçe, bu tam tersine bir güvensizlik sendromu da yaratabilir. Dolayısıyla, aradaki ilişki olumsuz etkilenmeye, ortak duygulanım azalmaya başlayabilir. Ve hatta kimi çatışmaları engellemek mümkün olmayabilir, anlaşmazlıklar peși sıra doğabilir (Erdoğan, 2002, 191). Böylelikle ortaya çıkacak uyumsuzluk iletişimin ilerleyişini gölgeleyecektir. Sosyal etkileşimi olumsuzlayan bu tür durumları ortadan kaldırmak için insanların birbirlerini yakından tanımaya ihtiyaçları vardır.

Öyle ki, açık iletişim sayesinde doğru bir iletişim ve ilişki durumu inşa edilebilir ve de güven kurulabilir. Bu şekilde insanlar birbirlerine açılabilir; tutum ve eğilimlerine, tercihte bulundukları değerlerine, karşılaştıkları sorunlarına yönelik karşılıklı gerçek duygu ve düşüncelerini paylaşarak doğru bilgilenim sağlarlar (Erdem, 2003, 175). Bu gerçeklik varoluşumuzun sosyal etkileşime ne denli dayalı olduğunun tüm emarelerini içinde taşımaktadır. Hayatın içinde birçok farklı gereksinim kişilerarası iletişim aracılığıyla giderilmektedir. Bir anlamda kendi varlığımızın değerini ortaya çıkarabilmek başkalarının varlığını hissetme duyarlılığına bağlı durumdadır. Dolayısıyla söz konusu duyarlılığın geliştirilmesi ile varoluşumuzun tadını çıkarmak olası olabilmektedir.

\section{Iletişimi Kişilerarası Kılan Başat Özellikleri}

İki insan birbirlerini fark ettikleri anda kişilerarası iletişim gerçekleşmeye başlar. $\mathrm{Bu}$ kaçınılamaz bir insani durumdur. Öncelikli olarak, konuşmanın başlaması iletişimin başlangıcı gibi hissedilmekle birlikte asıl başlangıcı sağlayan, konuşma kadar sessizliğin de iletişim potansiyeli ortaya koymasından ötürü, sözsüz şekilde gerçekleşen ilk fark etme anıdır. İletişimin, bir başka ifadeyle anlam aktarımının 
başlaması bu ilk fark etme anına dayanır. Bundan sonra tüm davranışlar bir ileti değeri taşıyacaktır, iletiler buna göre kodlanacak buna göre çözümlenecektir. Bu süreçte hem sözel hem sözsüz tüm iletişimsel durumlarla karşılaşılır. İnsanlar birbirlerini fark etmiş olmalarına karşın görmezlikten gelip konuşmadan yanlarından geçip gitseler bile iletişimin oluşmasını engelleyemezler. Bu nedenle, insanlar birbirlerinin farkında olduğu sürece iletişimden kaçınılamamaktadır. Görmemezlikten gelmek konuşmak istenmediğinin açık iletimi olduğu için, fark ettikten sonra iletişimi reddetmek olası görülmemektedir.

İnsanlar arasındaki etkileşim sembolik şekilde, daha açık bir ifadeyle göstergeler aracılığıyla gerçekleşmektedir. Yazılı, sözlü ve sözsüz olmak üzere her iletişim durumunda göstergeler evreninden yararlanılmaktadır. İletişim durumunu var kılan göstergelerin aktardığı anlamlardır. Doğrudan ya da dolaylı her iletişim durumunda kullandığımız göstergeler sosyalizasyon sürecindeki öğretinin sonucunda içselleştirilmiş olmaktadır. İnsanların diğer canlı varlıklara göre en temel farkı budur; Sosyalliğini ortaya koyan, kendi bilişsel yetkinliği ile oluşturmuş bulunduğu göstergeler aracılığıly anlam oluşturabilme ve aktarabilme yeteneğidir. Salt insanın kendine özgü bu yetkinliği tüm sosyal hayatı boyunca bir öğrenme süreci olarak devam etmekte, kendini yenileyebilmektedir (Eroğlu, 2000, 209).

Kişilerarası iletişimde sürecin yanında içerik de söz konusu olmaktadır. Söz konusu içeriği oluştururken, anlam aktarıcı olarak sadece sözcükler rol oynamaz. Paralinguistik denilen sözel olmayan iletişim biçimleri de önemli bir anlamsal işlev görürler, iletişimi daha doğal ve daha güçlü hale taşırlar. Anlamın hedeflenen içerikte oluşması, aktarılması, algılanması, yorumlanması belli paralinguistik esaslara göre de gelişmektedir. Öncelikle iletinin aktarıldığı zamanın önemi oldukça büyüktür. Doğru zaman doğru yer diye belirtilen bağlamın en anlamlı şekilde tespit edilmiş olması gerekmektedir. Aynı zamanda konuşucunun ifade tarzı, sesinin tonundaki rengi, jest ve mimikleri, postür duruşu sözsüz iletişim göstergeleri olarak anlamın aktarımında oldukça önemli rol oynamaktadır. Bu nedenle, iletişimde hem süreci hem de içeriği belirleyen göstergeleri doğru belirlemek ve etkili kullanmak gerekmektedir.

Dolayısıyla, ne söylendiği kadar nasıl söylendiği de iletişim sırasında oldukça önem taşır. Karşımızdaki kişi mesajın sadece sözel içeriğine değil, onu nasıl aktardığımıza da tepki geliştirir. Öyle ki iletişim süreci, ifade edilenlerin altında yatan duygu ve düşüncelerin anlaşılmasını sağlayacak ipuçları yaratmaktadır. Bu insanların daha duyarlılık geliştirdikleri bir boyuttur. Dolayısıyla, ne söylendiği kadar nasıl söylendiğine gereken dikkatin, olması gereken duyarlılığın sergilenmesi iletişimin olumlu ve etkili yürütülmesi açısından kaçınılmaz bir gereklilik yaratmaktadır.

İletişim sürecinde anlamı geliştiren karşılıklı etkileşimdir. $\mathrm{Bu}$ nedenle insanlar birbirlerini fark ettikleri anda başlayan kişilerarası iletişim sürecinde virtüel, bir başka ifadeyle göreceli şekilde konuşucu ve dinleyici olarak rol oynamaya başlarlar. Erving Goffman'ın (1973) Presentation of Self in Everyday Life adlı yapitında teatral sahne sunumu olarak betimlediği bu rol değişimi süreci lineer akıştan çıkarıp dairesel döngüye dönüştürür. Hiç şüphesiz, bu virtüel ortamda davranışı oluşturan salt akıl olamaz, duygu ve beden işbirliği de bu sürece dahil olmaktadır. Sonuçta, bu şekilde belirginlik kazanan davranışsal seçimlerimiz de tamamen kişisel niteliklerimizi yansıtmaktadır. 


\section{Iletişim Becerilerinin Kavramsal Açıııı}

Bilgi, duygu, düşünce ve inanç paylaşımı olarak kabul edilen iletişim etkileşimsel süreçte gerçekleşir. Söz konusu süreç bireyler arasında gerçekleştiği gibi gruplar ve toplumlar arasında da benzer şekilde işlevseldir. Özellikle iletişimi bir öğrenme süreci olarak da görmek olasıdır, bireylerin birbirlerinin toplumsal rol ve statülerinin yol açtığı farklı tutum ve davranışlarını anlamak amacıyla bu öğrenme süreci yürütülmektedir (Şimşek, 2003, 50).

Gerek süreçsel gerekse de sonuçsal olarak başarılı bir iletişim deneyimi için içselleştirilmesi gereken becerileri en temel çerçevede şu şekilde siralamak olasıdır: Karşılıklı sözel iletişim içinde olma, söz kesmeden dinleme, gerektiğinde duygu ve düşünceleri yansıtacak şekilde yanıt verme, örtük amaç taşımayan açık sorular yöneltme, beden dilini etkin kullanma ve doğru yetkinlikte çözümleme, iletilere yanıltıcı yanıtlar vermeyi tercih etmeme, doğruluktan uzaklaşmama, etkin dinleyici olma, göz temasının önemini kavrama ve iyi uygulama, karşıdaki kişiyi anlamaya çalıșma, empatik tepki geliștirme, geribildirimlerde 'Ben' iletilerini kullanma, eleştirilere karşı olumlu tavır takınma, dışa dönük davranışlar sergileme, atılgan, aktif olmaya çalışma, çatışma durumunda sorun çözücü tavır sergileme (Ceyhan, 2006, 367-379).

Bilindiği üzere, insan insana iletişim sürecinde sözlü aktarımlar düşünceleri açarken, beden dili ile gerçekleştirilen aktarımlar daha çok duyguları yansıtmaktadır. Başka bir anlatımla, sosyal etkileşimde sözlü aktarımlarla duyguların dile getirilmesinden daha çok düşüncelerin paylaşımı gerçekleștirilmektedir. Sözlü iletiler içeriğin düşünsel boyutunu ortaya koyarlar, genellikle duyguların dile getirilmesine elverişli değillerdir. Buna karşın, söz dıșı beden dili ile anlamın iletilmesi duygusal bilgiyi aktardığı için oldukça tamamlayıcı bir ekseni ortaya koymaktadır. İnsanın yaşam dünyasındaki karşılıklı ilişkilerde sözsüz kodlar da sözel kodların yanında başvurulan simgesel kodlardandır. Ve sözsüz olan kodların iletişimin anlamsal bütünlügünü ve etkililiğini oluşturmada çoğunlukla istemsiz ve kesintisiz şekilde, devamlı surette kullanıldığı görülmektedir. Dolayısıyla, sözsüz kodlar anlam aktarmada tıpkı sözel kodlar gibi oldukça önemli, 'olmazsa olmaz' bir işlevi yerine getirmektedir. Kişilerarası iletişimde en etkin işlevselliği ortaya koymaktadırlar. $\mathrm{Bu}$ konuda yapılan araştırmalar göstermektedir ki, sosyal etkileşimde sözsüz iletişim sözel iletişime oranla çok daha etkili olmaktadır. İnsanlar iletişim sırasında anlamsal gerçekliği daha çok sözsüz kodlardan edinmektedir. Bu nedenle, iletişimde etkinlik açısından yapılan karşılaştırmalarda sözsüz kodların \% 55 oranla en etkin araçsallığı ortaya koyduğu saptanmıștır. Buna karşın, sözel kodların etkililik oranı \% 7 olarak tespit edilirken, ses tonunun \% 38 oranında etki yarattığ (İzgören, 2000, 6). Araştırma oranlarına bakıldığında, anlam aktarmada en etkin araçsallığı beden dilinin gerçekleştirmekte olduğu net bir şekilde anlaşılmaktadır.

Oskay'ın (2001) çalışmalarında ortaya koyduğu üzere insanların sosyal etkileşim sürecinde aktarmak istedikleri gerek düşünsel gerek duygusal iletileri eksizsiz, etkili, başarılı şekilde gerçekleştirebilmeleri için dikkate almaları gereken birtakım durumlar bulunmaktadır. Bunların başında öncelikle iletinin içeriği gelmektedir. Konuşmanın içeriğinin hedefin ilgisini çekecek bir konudan oluşması oldukça önem taşır. Aynı zamanda iletiler aracılığıyla hedefte tutum değişikliğinin yaratılabilmesi için hedefin dünya görüşünü, değer yargılarını belli ölçüde bilmek gerekmektedir. $\mathrm{Bu}$ amaca ulaşabilmek için doğru kanal ya da kanalların belirlenmiş olması da 
yine gerekli bir hassasiyeti oluşturmaktadır. Son olarak sonuca ulaşmak, iknayı sağlayabilmek için iletişim sürecini etkin sürdürmek; kimi bilişsel ve duygusal dirençlerle karşılaşıldığında saldırgan üsluptan kesinlikle kaçınıp yeni argümanlarla iletişime devam etmek gerekmektedir (Oskay, 2001, 36- 41).

\section{Tutum ve Tutum Öğeleri}

Davranış bilimlerinin en anahtar kavramı tutumdur. İnsanın, dolayısıyla da insan davranışının sorgulanması davranış bilimlerinin çıkış noktasını oluşturmaktadır. Bu nedenle araștırmalarda en fazla yoğunluk tutum araştırmalarında yaşanmaktadır. İnsana dair her durumda tutum olgusu ile karşılaşılır. Davranışlarımızın kaynağında tutumlarımız vardır. Yapılan tanımlara göre de tutum herhangi bir psikolojik nesnellik karşısında takındığımız tüm tavır ve davranışlarımızın altında yer alan eğilimlerimizdir (İnceoğlu, 2011, 18). Bu kabul ediş de açıkça bir şekilde tutumun, davranış ile ilgili tüm araştırmalarda en merkezi kavramlarından biri olarak ele alınmasının doğallığını ortaya koymaktadır.

Murphy ve Newcomb'da da aynı değerlendirmelerle karşılaşılır. Sosyal etkileşim araştırmalarında kalkış noktasını tutumlar oluşturur. Tutumlara değinmeden elde edilecek bulguların davranışların temellerini açıklamada yeterli olmayacağı üzerinde durulmaktadır. Davranışın temel motivasyon kaynağı sorgulamalarında tutum temel belirleyici olarak dikkate alınmalıdır. İnsanı davranışa sevk eden en temel motivasyon tutum kaynaklıdır. Bu nedenle sosyal psikoloji disiplin olarak araştırmalarında en fazla eğilimi tutumlara yöneltmektedir. Bu özellikle 1940 yıllardan itibaren başlamış bir süreçtir. Ve bu alanda hem kuramsal boyut hem de yöntem bilimsel boyut ile ilgili önemli gelişmeler kat edilmiş, olgu olarak tutumlar tüm boyutları ile kapsamlı bir şeklide irdelenmeye başlanmıştır (İnceoğlu, 2011, 8-19). Sözgelimi bu gelişme sosyoloji alanındaki incelemelere de yeni boyutlar kazandırmıştır. Toplum, grup ve ayrıca kitle yapılarına ilişkin analizlerde tutumların da ele alınmasının haklı gereksinimi belirginlik kazanmıştır.

Dolayısıyla, topluluk ya da kitle içinde tutumları oluşturma, aynı zamanda da dönüştürme kabiliyeti sunan etken durumlar üzerinde daha fazla durulmaya, değişime yol açan durumların sondajına gidilmeye başlanmıştır. Toplumları yönlendirme özelliği bağlamında tutum ölçümlerine gittikçe daha fazla yer verilerek, bu alanda sosyoloji disiplininin kuram ve yöntemlerinin izleğinden hareket edildiği gözlemlenmektedir. İnsan davranışlarını konu alan bir bilim dalı olarak psikolojinin bu sondajlarda katkıları oldukça fazladır. Tüm bu çerçevedeki incelemelerde elbette yine ağırlıklı olarak, bireyin bilişsel aktivitesi ile duygusal devinimlerinin yol açtığı yaşam deneyimleri ile bu parametreler doğrultusunda oluşan algı setinin tutumdan kaynaklanan davranışlara nasıl aksettiği mercek altına alınmış durumdadır. Anlaşılacağı üzere, iletişim ile ilgili tüm incelemelerde tutumlar merkezi bir konuma yerleştirilmiş görülmektedir (İnceoğlu, 2011; Baysal, 1981).

İletişimde tutum kavramının işlevsel yapısından ötürü, psikoloji ve sosyal psikoloji alanında bu konudaki araştırmalara daha fazla yer verilmeye başlanmıştır. Böylelikle, kavramın her boyutuyla açıklanabilirliğini sağlayacak kuramsal altyapı gelişim göstermektedir. $\mathrm{Bu}$ çerçeveden hareketle, tutumların çevresel faktörlere bağlı olarak oluştuğu kabul edildiği gibi, dış etkenlere tepkiselliğin önsel dışavurumu olarak da ele alındığı görülmektedir. Bu yaklaşım bugün tüm tutum ile ilgili tanımların içeriksel ana temasını oluşturduğu için kavramın daha çok 
toplumsal tutum şeklinde ele alındığı anlaşılmaktadır (Baysal, 1981, 121)." Tüm bu gelişmelerin de tutumun kişisel bir olgu olmaktan çok toplumsallığını ortaya koymaya hizmet ettiğini belirtmek gerekir.

Son dönemlerde, tutumları oluşturan duygusal öğelerin yanı sıra bilişsel (zihinsel) boyutun da dikkate alınması gerektiği konusundaki yaklaşımlar da yine tutum çalışmalarında görülen bir başka ortak paydayı oluşturmaktadır. Ancak bazı araştırmacılar için tutumlar hala yalnızca duygusal tepki ön eğilimleri olarak kabul edilmiş olsa da, bugün artık zihinsel süreçlerin de tutumların oluşmasında ağırlıklı rol oynadıkları kabul görmektedir. Tutumlar ile ilgili yapılan araştırmalarda ulaşılan bir diğer ortak payda da, zihinsel ve duygusal aktivitelerin yanı sıra inancın da tutum oluşumunda rol oynadığı, bu üçlü mekanizmanın tutumlarda örgütlü bir ilişki içinde bulundukları yönündedir (Kalkan, 2011, 6). Ayrıca bu örgütselliğin sürekliliğine dikkat çekilmekte, insanın karşılaştığ her durumda söz konusu olmasından dolayı tutumların oluşumunda öğrenme sürecinin varlığına ve önemine işaret edilmektedir.

Öğrenme süreci üzerine yapılan vurgulama aslında aynı zamanda tutumların 'değişebilirlik boyutu'nun da dikkate alınması gerekliliğini ifade etmektedir. Tutum değişmez, durağan bir olgu olarak görülmemelidir. Bunların yanı sıra, tutum incelemelerinde dikkate alınmasında hemfikir olunan bir diğer ortak nokta da, psikolojik değişken niteliğinden dolayı tutumların gözlemlenmesindeki güçlükleridir. Gizli değişken özelliği gösterdikleri kabul edilmektedir. Bu nedenle, ancak, sözel kodlarla birlikte jest, mimik, tavır vb. sözsüz kodlardan yola çıkılarak belirginlikleştirilmeleri söz konusu edilmektedir. Bu noktada ayrıca tutumları motivasyon olgusuyla da ilişkilendirmekte fayda vardır. Açıkça belirtmek gerekirse, tutum açıklamalarında 'sosyalizasyon süreci' kesinlikle dikkate alınmadan geçilemez. Özetle ifade etmek gerekirse, tutumun kavramsal bir nitelik kazanmasında duygusal süreçlere eșlik eden bilișsel aktiviteler ile birlikte, sosyalizasyon sürecinin belirleyicileri olarak öğrenme ve motivasyon olguları başat rol oynamaktadır (Allport 1967, 68).

En yalın anlatımla, yansıttığı öngörülen, gözlemlenebilir kimi davranışsal aktiviteler sayesinde tutumun varlığı hissedilebilmektedir. Öyle ki;

\begin{abstract}
Herhangi bir tutum konusuna karşı, herhangi bir davranış söz konusu değilse, böyle bir tutum, çevredeki bireylerce gözlemlenemeyeceğinden bilinemez. Bu nedenle, tutum olgusunda, en azından psikolojik gözlem açısından, davranışsal öğe kavramına yer vermek gerekir. Tutumları zihinsel, duygusal, davranışsal öğelerden oluşan psikolojik değişkenler olarak ele aldığımızda, ne kadar karmaşık süreçlerin etkisinde oluştukların görmekteyiz. Bu üç öğe, genellikle kendi aralarında ve aynı sınıfa giren uyaranlar arasında, bireyin çevresine uyumunu kolaylaştırma açısından, bir tutarlılık oluştururlar (Kağıtçıaşı, 1999, 106).
\end{abstract}

\title{
5. Empatinin İletişimdeki Fonksiyonu
}

Yunanca bir terim olarak 'empatheia', 'insanın içini hissetme' anlamına gelmektedir. İlk kez "diğerinin öznel deneyimini algılayabilme yeteneği" olarak kullanılmıştır (Goleman, 1995). Empati, en yaygın ve en anlaşılır şekilde, insanın karşısındaki kişinin duygu, düşünce ve davranışlarını anlayabilmesi için kendisini onun yerine koyarak değerlendirme yapması demektir. Aynı zamanda yaptığı değerlendirmeyi karşısındaki kişiye iletmesi gereklidir. Bu paylaşım yapılmazsa eğer empatik tepki tamamlandırılmamış olur. Empati tutumu gelişmiş insanların toplumsal değeri 
yükselir, başkaları tarafından daha fazla sevilirler. Bu da onların onaylanarak toplumsal kabulünü sağlar. Nitekim bugüne kadar yapılan araştırmalar da, özellikle liderlik özelliğine sahip yöneticilerde yüksek empati eğilimi saptanmıştır. Empati kurma becerisi bir anlamda liderlik için zorunlu koşul niteliği taşımaktadır. Bilindiği üzere, insanın kendisini başkasının yerine koyabilmesi hiç kolay değildir, ciddi ve samimi bir çaba gerektirir. Ancak empatik eğilimi yüksek insanlar bu psikolojik yatkınlığa sahiptirler. Bir beceri olarak da alınması gereken empati kurma, yapısal özelliklerinden ötürü toplumda liderlik vasfı taşıyan insanlarda daha çok gözlemlenir. Bu anlamda, liderlik vasıfları ile empatik tepki arasındaki yüksek korelasyon dikkate alınırsa, söz konusu vasıfların önemini anlatmak daha da kolaylaşacaktır. İnsanın öncelikli olarak kendini iyi tanıması ve anlatabilmesi, duygu ve düşüncelerini açıkça ifade edebilmesi, toplum içinde uyumlu olabilmesi, başkalarının varlığına saygı duyması ve bu saygıyı gösterebilmesi, bu şekilde yüksek toplumsal duyarlılık içinde bulunabilmesi sıralanabilecek başat liderlik vasıfları olarak kabul edilmektedir. İşte tüm bu özellikleri kendi bünyesinde içselleştirmiş, doğal ve samimi şekilde insan ilişkilerine yansıtabilen insanlar lider vasıflıdırlar ve empati kurma becerileri de oldukça yüksek olur (Gürgen, 1997, 139-140).

Dökmen (1997)'nin de belirttiği gibi, empatik tavır kişilerarası iletişimde başarıyı belirleyen, etkililiği sağlayan, sosyal ilişkilerimizi olumlu yönde etkileyen başat etmenlerden biridir. Karşımızdaki kişinin duygu, düşünce ve davranışlarının nedenlerini anlayabilmek için, onun dünyasına girmek, onun psikolojik paradigmasına göre dünyayı algılamaya çalışmak gerekir. Her insanın dünyayı algılayış biçimi farklıdır elbette, önemli olan bu farklılığın altında yatan temel etkenleri görebilmek, farkedebilmek, algllayabilmektir. Bilindiği üzere, insan sosyal ilişkilerinde duygularını sözlerle anlatmanın yanında sözsüz ifadeleri de tercih etmektedir. $\mathrm{Bu}$ nedenle, karşımızdaki insanların ne düşündüğü ne hissettiğini iyi anlayabilmek için dil-ötesi diye kabul edilen paralinguistik olguları da doğru çözümlemek gerekmektedir. Karşımızdaki insanı doğru anlayabilmek için, beden duruşu, yüz ifadesi, ses tonu ve buna benzer pek çok dil ötesi davranışı analiz etme becerisine de sahip olmak gerekmektedir. Bu nedenle, empati, çocukluktan itibaren içinde bulunulan gelişim sürecinde edinilmeye başlanan bir olgudur. En etkin iletişim tavrı olarak kabul edilmektedir. Bir bakıma, başkalarının dünyadaki kendiliği ile ilgili bilgisini doğru anlayabilme becerisinin gelişimi ile doğru orantılı bir gelişim gösterir.

Empatik tepki verme aslında bir anlamda kişinin kendiliği ile ilgili bilgiye de sahip olduğunun göstergelerini taşımaktadır. Kişi kendini ne kadar iyi tanıyorsa o kadar empatik olabilecektir. Ayrıca bu tepkisi sayesinde de kendiliği ile ilgili bilgi dağarcığını genişletebilmektedir. Kendiliğine ilişkin farkındalık bir anlamda empatik tavırdan geçmektedir. Bu anlamda empatik eğilim iki yönlü fayda ekseni sunmaktadır.

Kendisi ile ilgili bilgisi doğru olan, farkındalığı yüksek olan bireyler, karşılarındaki kişinin yaşadıkları ile ilgili durum ya da durumları da güçlü sezgileri ile rahatlıkla kavrayabileceklerdir. Farkındalığa dayalı gelişen sezgi gücü ile de bireylerin karşılaştıkları farklı durumlara adapte olmaları kolay olacaktır (Öz, 1998). Elbette empatik iletişim için öncelikle karşımızdaki kişinin varlığını kabul etmek gerekir. Daha sonra da, farklı dünya görüşüne sahip olabileceği, farklı değer yargıları geliștirmiş olabileceği, bizden farklı bir inancı olabileceği vb. farklılıklar görülmelidir. 
Tüm bu konulardaki farkındalık empatik iletişimi kolaylaştırıp, karşımızdaki insanı bir ön kabul ile haklı ya da haksız olarak kesin surette yargılamanın önünü kesecek, olayların altında yatan gerçek sebeplerin görülmesine çaba harcanmasına yol açacaktır (Harrow, 1999).

Rogers'a göre de, empatik iletişim için bir başkasının yaşam dünyasını anlamak gerekir, o kişinin iç dünyasına girmek, onun yaşadıklarını hissetmek gerekir, ancak girdiği bu iç dünyada kişinin kendiliğini korumass, kendiliğinden vazgeçmemesi gerekir. Bu nedenle, sempatik tavır içinde bulunup, karşımızdaki kişiyi tamamen onaylama yaklaşımı empatik iletişim olarak kabul edilmez. Anlamaya çalışmak onaylamak demek değildir, salt herhangi bir iletişim durumunda karşılaşılan duygu, düşünce, tavır ve davranışlara yol açan gerçek nedenleri görebilmek için çaba sarfetmek demektir. Bunun için yüksek bir hassasiyete sahip olmak ve aynı zamanda tespitlerle ilgili karşımızdaki kişiye de geribildirimde bulunmak gerekir (Mete ve Gerçek, 2005). Morse, Anderson ve arkadaşları da (1992) empatinin dört önemli boyutunu duygusal, moral, bilişsel, davranışsal boyut olarak saptamışlardır (Mete ve Gerçek, 2005). Söz konusu boyutları açımlamak gerekirse;

- Duygusal boyut; bir kimsenin duygularını hayal yoluyla hissetme becerisi,

- Moral boyut; duyguları anlamak için gerekli olan iç motivasyon,

- Bilişsel boyut; entellektüel ve analitik becerileri içeren diğerlerinin duygularını anlayabilme yeteneği,

- Davranışsal boyut; aktif dinleme, kritik etme (reflection) gibi iletişim becerileri.

Bilindiği üzere, kişilerarasındaki iletişimin sağlıklı ve etkili olabilmesi için üç temel ön koşul öne sürülmüştür. İlki doğallık'tır; kişinin açık ve dürüst olmasıdır. İkincisi kabul etme/saygı'dır; kişilerin birbirlerinin varlığına saygı duymaları, birbirlerini kendilerine özgü nitelikleri ile kabul etmeleridir. Üçüncüsü de empati'dir; kişilerarası iletişimde bireyin kendisini karşısındakinin yerine koyabilmesi, bir başka ifadeyle onun bakış açısı ile olayları değerlendirebilmesidir (Korkut, 1997).

Tutum ve duyguları çözümlemeye çalışarak empatik iletişime başlamak önemlidir, ancak bu şekilde insanların dünya görüşleri ile duygulanımlarını anlamak olanaklı olacaktır (Navaro, 2000). Etkin dinleme becerisi de bu noktada dikkate alınması gereken bir iletişim becerisidir. Görünüște, savunmacı vb. negatif dinleme tarzları empatiyi engeller. Gerçekten de karşımızdaki insanı söz konusu bu negatif yansımalardan uzak, etkin dinlediğimizde empatik tavır gelişmektedir. Bu nedenle dinleme becerisi empati kurma sürecinin ilk aşaması olarak görülmektedir. Karşıdaki kişiyi gerekli ölçülerde, farklı kanaldan dinlemeli, tutum ve duygularını kişinin kendi dilinden doğru anlamaya çalışılmalıdır. Hiç şüphesiz, etkin dinleme becerisi empatik tavır geliştirmede oldukça önemlidir, empatinin gerçekleşmesindeki ilk adımdır, ancak bu nedenle, salt dinleme becerisi sayesinde empatik iletişimin tam olarak sağlanabildiği ifade edilemez.

Kuramsal perspektife göre de, empatik iletişimin 'bilişsel' ve 'duygusal' olmak üzere iki temel ögesi bulunmaktadır. 'Karşısındakini anlamak' empatinin bilişsel yönünü ifade ederken, 'karşısındakini hissetmek' ise duygusal yönü ortaya koymaktadır. İlgili literatürde kavram genel olarak bu iki öge çerçevesinde ele alınırken, kimi araştırmacılar daha çok bilişsel boyutu öne çıkarmaktadır. Bazı araştırmacılar ise söz konusu bu iki ögeye bir üçüncü öge de eklemektedir. Sözgelimi Hoffman 
için empatik tepkide bilişsel ve duygusal ögelerinin yanı sıra güdüsel öge de yer almaktadır (Dökmen, 1988).

Bir empati modeli geliştiren Barrett-Lennard'a göre de, empati tek yönlü değildir, iki kişi arasındaki karşılıklı dairesel nitelikli bir iletişim şeklinde gerçekleşir. Rogers'a göre de, 'anla', 'hisset' ve 'göster' basamakları empatik iletişimin üç temel işlevsel basamağını oluşturur. Empatik tavır da bu üç işlevin ardı sıra yerine getirilmesi ile gerçekleşir (Dökmen, 1988).

\section{Araştırmanın Amacı ve Metodolojisi}

Kırgızistan - Türkiye Manas Üniversitesi ile Erciyes Üniversitesi'nde eğitim gören İletişim Fakültesi öğrencilerinin iletişim becerilerinin inşasında gerek kişisel özelliklerinin gerek ise empatik eğilimlerinin ne derece yer aldığını araştırmak çalışmanın temel amacını oluşturmaktadır.

Araştırma yöntemi başlığı altında bu çalışmanın tasarımı ortaya konularak, bunun için ilk olarak kullanılacak teknikler ve kullanım biçimleri ile ilgili aktarımda bulunulmuştur. Araştırmada, İletişim Fakültesi öğrencilerinin empatik eğilim ve iletişim beceri düzeylerini ortaya koyabilmek ve sonrasında ise her iki değişken arasında bir ilişkinin olup olmadığını analiz etmek amacıyla var olan durumu betimleyip, verilerin açıklanmasını ve yorumlanmasını açıklayan tarama modelinden yararlanılmıștır (Altunışık vd., 2005, 61-2, Neuman, 2006, 494).

Araştırmada kullanılacak teknikler esas olarak araştırmanın amacına göre belirlenir. Ancak bu noktada devreye araștırmacının bilgi ve deneyim alt yapısı da girmektedir. (Aziz, 2008, 73). Sosyal bilimsel araștırmalarda problematiğe göre ya nitel ya da nicel sorgulama yapılmaktadır. Bu iki paradigmada da gözlem kaçınılmaz olarak birincil kaynak olarak kullanılır. Bunun yanında anket ve mülakat (görüşme tekniği) da birincil kaynaktan bilgi edinme teknikleri olarak tercih edilebilmektedir (Altunışık vd., 2005, 68). Bu makalede de kuramsal perpspektif için veri toplama tekniği olarak alanyazın incelemesi gerçekleştirilmiştir; emprik araştırma için ise anket uygulanarak konu ile ilgili birincil veri kaynaklarına ulaşılması hedeflenmiştir.

Araştırmada üç kesitli bir soru formu kullanılmıştır. İlk kesitte öğrencilerin demografik özellikleri bulunurken, ikinci soru kesitinde empatik eğilim ölçeği (EEÖ), üçüncü soru kesitinde ise iletişim becerileri ölçeği (İBÖ) yer almıştır.

Soru formunun ikinci bölümünde, Üstün Dökmen (1988) tarafından geliştirilen Likert tipi 20 maddeden oluşan empatik eğilim ölçeği kullanılmıştır. Soru formunun son kısmında da Aslı Bugay ve Fidan Korkut Owen (2014) tarafından geliştirilen 25 maddeden oluşan likert tipi iletişim becerileri ölçeği yer almaktadır. Söz konusu 25 madde de kendi içerisinde 4 alt kategoriye ayrılmaktadır. Bunlar, İletişim İlkeleri ve Temel Beceriler (İITB)', 'Kendini Ífade Etme (KİE)', 'Etkin Dinleme ve Sözel Olmayan İletişim (EDSOI)', '̇letişim Kurmaya İsteklilik (İKI)'şeklindedir.

Araștırmanın inceleme alanını, örneğini seçtiği ve edindiği, sonuçlarını genelleştireceği Kırgızistan-Türkiye Manas Üniversitesi ile Erciyes Üniversitesi İletişim Fakülteleri oluşturmaktadır. Bu bağlamda, Kırgızistan Türkiye Manas Üniversitesi İletişim Fakültesinde eğitim-öğretimde bulunan Kırgız öğrenciler ile Erciyes Üniversitesi İletişim Fakültesinde eğitim-öğretim faaliyetinde bulunan Türk öğrencilere kolay ulaşılabilir durum örneklemesi yöntemi uygulanmıștır. 
Problemin açıcça anlaşılmasını, verilerin toplanmasını, analizini ve en az iki değişken arasında kestirilen ilişkiyi açıklamayı amaçlayan çalışmanın hipotezleri, öğrencilerin iletişim becerileri, empati eğilimleri ve kişisel özelliklerine ait sorular gruplandırılarak sistematize edilmiştir.

Araştırmada nicel verilerin analizinde ilk kesitteki sorgulamalarda nitel kişisel değişkenler ile ilgili yüzde-frekans dağılımı elde edilmiştir. İkinci ve üçüncü kesitteki empatik eğilim ölçeği ile iletişim becerileri ölçeğinde yer alan sorgulamaların değerlendirilmesinde de yüzde, frekans ve aritmetik ortalamalar temel alınmıştır. Aynı zamanda katılımcıların kişisel özellikleri ile empatik eğilim ölçeğine ve iletişim becerilerine ait değişkenler arasında 0.05 anlamlılık düzeyinde farklılık analizi parametrik testler aracılığıyla sağlanmıştır. Bu amaçla $\mathrm{T}$ Testi ile Varyans (Anova) Analizi kullanılmıştır. Bunların yanı sıra, değişkenler arasında herhangi bir ilişki olup olmadığı da sorgulanmıştır. Var olan ilişkiselliğin derecesini ve anlamlılığını belirlemek amacıyla anket formunda yer alan iletişim becerilerine ait değişkenler ile empatik eğilim konusuyla ilgili değișkenler arasında Korelasyon Analizi'ne gidilmiştir. İki değişken arasındaki ilişkiyi ölçmeye yaradığı için bu analiz tercih edilmiştir (Kalaycı, 2006, 115). Cronbach Alpha katsayısı ile de araştırma ölçeğin güvenilirliği test edilmiş bulunulmaktadır.

\section{Araştırmanın Bulguları}

İlgili kuramsal çerçeve ile desteklenen bu kısımda anket yoluyla birincil kaynak verilerine ulaşılmıştır. Söz konusu verilerin nicel analiz teknikleri ile bulguya dönüştürülmesi sağlanmıştır. Son olarak da, elde edilen bulguların değerlendirilmesi gerçekleştirilmiştir.

\subsection{Araştırmanın Geçerlilik ve Güvenilirliği}

Çalışmada ölçeklerin güvenilirliğini belirlemede sosyal bilimlerle ilgili araştırmalarda oldukça sık kullanılan Cronbach Alpha katsayısı hesaplanmıştır. Anketin güvenilirlik katsayısı \% 85 (Manas Ünv.) ve \% 82 (Erciyes Ünv.) çıkmıştır. Söz konusu değerler "1" e yakın bir değer olduğundan anketin yüksek derecede güvenilir olduğu belirtilebilir. Ankette kullanılan sorular yukarıda da ifade edildiği gibi literatür taraması sonucunda bu alanda yapılmış ve etkili sonuçları ortaya çıkaran referanslardan temin edilmiştir. Bu yönüyle ankette kullanılan soruların araştırmada hedeflenen sonuçlara ulaşmada geçerli olduğu düşünülmektedir.

\subsection{Araştırmaya Katılan Öğrenciler ile İlgili Genel Bilgiler}

Araştırmaya katılanların cinsiyet, kardeş sayısı, anne ve babanın aldığı en yüksek eğitim durumu gibi özelliklere ilişkin yüzde-frekans dağılımları Tablo 1'de yer almaktadır. 
Tablo 1: Araştırmaya Katılan Öğrenciler ile İlgili Tanıtıcı Bilgilere İlişkin Frekans ve Yüzde Dağılımları

\begin{tabular}{|l|l|c|c|c|c|}
\hline \multirow{2}{*}{ Kişisel Bilgiler } & \multicolumn{2}{c|}{ Frekans } & \multicolumn{2}{c|}{ Yüzde(\%) } \\
\cline { 2 - 6 } & \multirow{3}{*}{ Cinsiyet } & Kırgız & Türk & Kırgız & Türk \\
\hline \multirow{5}{*}{ Kardeş Sayısı } & Kadın & 98 & 87 & 54.7 & 48.1 \\
\cline { 2 - 6 } & Erkek & 81 & 94 & 45.3 & 51.9 \\
\hline & Kardeşim yok & 5 & 9 & 2.8 & 5 \\
\cline { 2 - 6 } & Bir kardeş & 31 & 54 & 17.3 & 29.8 \\
\cline { 2 - 6 } & İki kardeş & 29 & 30 & 16.2 & 16.6 \\
\cline { 2 - 6 } & Üç kardeş & 46 & 43 & 25.7 & 23.8 \\
\cline { 2 - 6 } & Dört ve daha fazla & 68 & 45 & 38 & 24.9 \\
\hline \multirow{5}{*}{ Annanın Eğitimi } & Liseden daha düşük & 18 & 88 & 10.1 & 48.6 \\
\cline { 2 - 6 } & Lise & 44 & 58 & 24.6 & 32 \\
\cline { 2 - 6 } & Lisans & 57 & 28 & 31.8 & 15.5 \\
\cline { 2 - 6 } & Lisans üstü & 55 & 6 & 30.7 & 3.9 \\
\hline & Liseden daha düşük & 21 & 121 & 11.8 & 66.9 \\
\cline { 2 - 6 } & Lise & 37 & 38 & 20.8 & 21 \\
\cline { 2 - 6 } & Lisans & 68 & 18 & 38.2 & 9.9 \\
\cline { 2 - 6 } & Lisans üstü & 52 & 3 & 29.2 & 2.2 \\
\hline
\end{tabular}

Tablo 1'de araştırmaya katılan öğrencilerin cinsiyet dağılımlarında, Kırgız öğrencilerin \% 54.7'sini kız öğrencilerin oluşturduğu, \% 48.1'ini ise erkek öğrencilerin oluşturduğu görülmektedir. Türk öğrencilerin ise \% 45.3'ünü erkek öğrenciler oluştururken, 51.9'unu kız öğrenciler oluşturmaktadır. Araştırmaya katılanların kardeş sayısına bakıldığında ise, Kırgız öğrencilerin kardeş sayısı oranının biraz daha yüksek olduğunu görmek mümkündür. Kırgız öğrencilerin \% 38'inin dört ve daha fazla kardeșe sahip oldukları, Türk öğrencilerin ise \% 29.8'itek kardeşleri olduğunu belirtmişlerdir.

Araştırmaya katılan öğrencilerin ebeveynlerinin eğitim durumlarına bakıldığında, Kırgız öğrencilerin büyük bir çoğunluğunun gerek baba gerek ise annelerinin lisans ve lisansüstü eğitim almış oldukları görülmektedir. Türk öğrencilerin çoğunluğunun ise baba ve annelerinin eğitim durumlarının lise ve daha düşük derecede olduğu görülmektedir.

\section{3. Öğrencilerin İletişim Becerilerine ve Empatik Eğilimlere Ilişkin Değerlendirmeleri}

Tablo 2'de hem Erciyes Üniversitesi hem de Manas Üniversitesi İletişim Fakültesi öğrencilerinin İletişim Becerileri Ölçeğine ve Boyutlarına yapmış oldukları değerlendirmeler yer almaktadır. 
Tablo 2: Öğrencilerin İletişim Becerileri Ölçeğine ve Boyutlarına İlișkin Değerlendirmeleri

\begin{tabular}{|c|c|c|c|c|c|c|c|c|c|c|c|}
\hline \multicolumn{12}{|c|}{ İletişim Becerileri Ölçeği } \\
\hline \multirow[t]{2}{*}{ Ölçek } & \multicolumn{2}{|c|}{$\begin{array}{c}\text { N ( Katılımc } \\
\text { Sayısı) }\end{array}$} & \multicolumn{2}{|c|}{ Minimum Puan } & \multicolumn{2}{|c|}{ Maksimum Puan } & \multicolumn{2}{|c|}{$\begin{array}{l}\text { Aritmetik } \\
\text { Ortalama }\end{array}$} & \multicolumn{2}{|c|}{ Standart Sapma } & \multirow[t]{2}{*}{$\begin{array}{l}\text { Önem } \\
\text { Seviyesi }\end{array}$} \\
\hline & KG & TR & KG & TR & KG & TR & KG & TR & KG & TR & \\
\hline $\begin{array}{l}\text { İletişim } \\
\text { Becerileri }\end{array}$ & 179 & 181 & 2.4 & 2.83 & 4,96 & 5.00 & 3,8613 & 4,0678 & 43794, & 47158, & ,000 \\
\hline \multicolumn{12}{|c|}{ İletişim Becerileri Ölçeği Boyutları } \\
\hline \multirow[t]{2}{*}{ Ölçek } & \multicolumn{2}{|c|}{$\begin{array}{c}\text { N ( Katılımc } \\
\text { Sayısı) }\end{array}$} & \multicolumn{2}{|c|}{ Minimum Puan } & \multicolumn{2}{|c|}{ Maksimum Puan } & \multicolumn{2}{|c|}{$\begin{array}{l}\text { Aritmetik } \\
\text { Ortalama }\end{array}$} & \multicolumn{2}{|c|}{ Standart Sapma } & $\begin{array}{l}\text { Önem } \\
\text { Seviyesi }\end{array}$ \\
\hline & KG & TR & KG & TR & KG & TR & KG & TR & KG & TR & \\
\hline $\begin{array}{l}\text { İletişim İlkeleri } \\
\text { ve Temel } \\
\text { Beceriler }\end{array}$ & 179 & 181 & 2.50 & 2,33 & 5.00 & 5,00 & 3.8565 & 3,9726 & ,49881 & ,51291 & ,007 \\
\hline $\begin{array}{l}\text { Kendini Ifade } \\
\text { Etme }\end{array}$ & 179 & 181 & 2.25 & 2,25 & 5.00 & 5,00 & 3.8948 & 4,0562 &, 55315 &, 56607 & ,000 \\
\hline $\begin{array}{l}\text { Etkin Dinleme ve } \\
\text { Sözel Olmayan } \\
\text { İletişim }\end{array}$ & 179 & 181 & 1.83 & 2,20 & 4.83 & 5,00 & 3.8991 & 4,1890 & 51968, &, 57489 & ,000 \\
\hline $\begin{array}{l}\text { İletişim Kurmaya } \\
\text { İsteklilik }\end{array}$ & 179 & 181 & 2.40 & 2,20 & 5.00 & 5,00 & 3.8209 & 4,1193 & ,57308 & ,61347 & ,022 \\
\hline
\end{tabular}

Tablo 2'de de görüldüğü üzere Manas Üniversitesi'nde eğitim gören Kırgız öğrencilerin iletişim becerilerine ilişkin sorularına yönelik değerlendirmeleri ortalama 3,86'dır. Türk öğrencilerin iletişim becerilerine ilişkin değişkenlere yapmış oldukları değerlendirmenin ortalaması ise 4,06'dır.

Tablo 2'de aynı zamanda iletişim becerileri ölçeği boyutlarına ilişkin öğrencilerin değerlendirmeleri yer almaktadır. 'İletişim ilkeleri ve temel becerileri' boyutuna ilişkin sorulara Kırgız öğrencilerin yapmış olduğu değerlendirmelerin ortalaması 3,85'dir. Türk öğrencilerin değerlendirmeleri ortalaması ise 3,97'dir. İletişim becerilerinin 'Kendini ifade etme' boyutunda ise Kırgız öğrencilerin değerlendirmeleri 3,89'dur. Türk öğrencilerin değerlendirmeleri ortalaması ise 4,05'dir.Tablo 2'de aynı zamanda 'Etkin dinleme ve sözel olmayan iletişim' boyutuna ilişkin sorulara, Kırgız öğrencilerin değerlendirmeleri ortalaması 3,89'dur. Türk öğrencilerin değerlendirmeleri ortalaması ise 4,18'dir. 'İletişim kurmaya isteklilik' boyutuna ilişkin sorulara ise Kırgız öğrencilerin değerlendirmeleri ortalaması 3,82'dir. Türk öğrencilerin değerlendirmeleri ortalaması ise 4.11'dir.

Tablo 2'ye genel olarak bakıldığında, gerek Kırgız öğrenciler gerek ise Türk öğrenciler İletişim becerilerine ilişkin soruların genel ortalamasında (KG 3.86; TC 4.06) birbirlerine yakın bir sonuç ortaya çıktığı görülmektedir.

Aynı zamanda Tablo 2'de Kırgız öğrenciler ile Türk öğrencilerin iletişim becerileri boyutlarına ait sorulara yaptıkları genel değerlendirmelerde 0.05 önem seviyesinde anlamlı farklılıklar bulunup bulunmadığı bağımsız örneklem t-Testi ile incelenmiștir. Söz konusu ortalamalara bakıldığında, her dört (4) iletişim boyutunda da anlamlı farklılık söz konusudur. Bir başka ifadeyle, Türk öğrencilerin Kırgız öğrencilere göre çok az da olsa iletişim becerilerinin ortalamasının yüksek olduğu görülmektedir. 
Tablo 3: Öğrencilerin Empatik Eğilim Ölçeğine İlişkin Değerlendirmeleri

\begin{tabular}{|c|c|c|c|c|c|c|c|c|c|c|c|}
\hline \multicolumn{12}{|c|}{ Empatik Eğilim Ölçeği } \\
\hline \multirow[t]{2}{*}{ Ölçek } & \multicolumn{2}{|c|}{$\begin{array}{l}\text { N (Katılımcı } \\
\text { Sayısı) }\end{array}$} & \multicolumn{2}{|c|}{$\begin{array}{l}\text { Minimum } \\
\text { Puan }\end{array}$} & \multicolumn{2}{|c|}{$\begin{array}{l}\text { Maksimum } \\
\text { Puan }\end{array}$} & \multicolumn{2}{|c|}{$\begin{array}{l}\text { Aritmetik } \\
\text { Ortalama }\end{array}$} & \multicolumn{2}{|c|}{ Standart Sapma } & \multirow{2}{*}{$\begin{array}{l}\text { Önem } \\
\text { Seviyes }\end{array}$} \\
\hline & KG & TR & KG & TR & KG & TR & KG & TR & KG & TR & \\
\hline $\begin{array}{l}\text { Empatik } \\
\text { Eğilim } \\
\text { Ölçeği }\end{array}$ & 179 & 181 & 2.50 & 2,30 & 4.7 & 4,83 & 3,5498 & 3,4536 & ,38228 & ,41320 & ,002 \\
\hline
\end{tabular}

Tablo 3'de Kırgızistan-Türkiye Manas Üniversitesi ile Erciyes Üniversitesi İletișim Fakültesi öğrencilerinin Empatik Eğilim Ölçeğine yapmış oldukları değerlendirmeler yer almaktadır. Tabloda da görüldüğü üzere Manas Üniversitesi'nde eğitim gören Kırgız öğrencilerin empatik eğilim ölçeğinin sorularına ilişkin değerlendirmeleri ortalaması 3,54'dür. Türk öğrencilerin empatik eğilim ölçeğine ilişkin değişkenlere yapmış oldukları değerlendirmenin ortalaması ise 3,45'dir. Söz konusu bu ortalamaları genel olarak değerlendirmek gerekirse, gerek Kırgız gerek ise Türk öğrencilerin empatik eğilim ortalamalarının olumlu yönde ancak çok yüksek düzeyde olmadığını söylemek mümkündür.

Tablo 3'te aynı zamanda Kırgız öğrenciler ile Türk öğrencilerin empatik eğilimlerine ait sorulara yaptıkları genel değerlendirmelerde 0.05 önem seviyesinde anlaml farklılıklar bulunup bulunmadığı bağımsız örneklem $t$-Testi ile incelenmiş ve sonuçlar Tablo 3'de verilmiştir. Buna göre öğrencilerin ortalamalarında (KC 3.54; TC 3.45) anlamlı farklılık söz konusudur. Bu durum Kırgız öğrencilerin empatik eğilim ortalamasının Türk öğrencilere göre daha çok olduğunu göstermektedir.

Aynı zamanda çalıșmada öğrencilerin gerek iletişim becerilerine gerek ise empatik eğilim ölçeğine ilişkin değerlendirmelerinin, öğrencilerin cinsiyeti, aile eğitim durumları ve kardeş sayısı gibi özelliklere göre 0.05 önem seviyesinde anlamlı farklılık yaratıp yaratmadığı bağımsız örneklem t-Testi ve Varyans Analizi (anova) ile incelenmiştir. Ancak gerek Kırgız öğrencilerde gerek ise Türk öğrencilerde söz konusu bu bağımsız değişkenlere göre ne iletişim becerisinde ne de empatik eğilimde, 0.05 önem seviyesinde anlamlı bir farklılık saptanmamıștır. Bir başka ifadeyle, öğrencilerin iletişim becerileri ve empatik eğilimleri kişisel özelliklerine göre farklılık göstermemiştir.

\section{4. Öğrencilerin Uyruğuna Göre Empatik Eğilim ölçeği ile İletişim Becerileri Boyutlarının Korelasyon Analizi}

Araştırmanın bu kısmında öğrencilerin empatik eğilimleri ile iletişim becerileri boyutları arasında anlamlı bir ilişki olup olmadığını araştırmak için korelasyon analizi uygulanmıştır.

Tablo 4: Empatik Eğilim Ölçeği ile İletișim Becerileri Alt Boyutları Arasında Korelasyon Katsayıları

\begin{tabular}{|c|c|c|c|c|c|c|c|c|c|}
\hline \multirow[t]{2}{*}{ Ölçek } & \multirow{2}{*}{$\begin{array}{c}\text { Spearmann } \\
\text { Sıra Korelasyon } \\
\text { Katsayıları }\end{array}$} & \multicolumn{2}{|c|}{$\begin{array}{l}\text { İletişim İkeleri ve } \\
\text { Temel Beceriler }\end{array}$} & \multicolumn{2}{|c|}{$\begin{array}{l}\text { Kendini İfade } \\
\text { Etme }\end{array}$} & \multicolumn{2}{|c|}{$\begin{array}{c}\text { Etkin Dinleme ve } \\
\text { Sözel OImayan } \\
\text { İletişim }\end{array}$} & \multicolumn{2}{|c|}{$\begin{array}{l}\text { İletişim Kurmaya } \\
\text { İsteklilik }\end{array}$} \\
\hline & & Kırgız & Türk & Kırgız & Türk & Kırgız & Türk & Kırgız & Türk \\
\hline \multirow{3}{*}{$\begin{array}{l}\text { Empatik } \\
\text { Eğilim }\end{array}$} & Katsayılar & $478^{\star \star}$ & ,299** &, $320^{\star \star}$ & ,105 &, $314^{\star \star}$ & ,120 & $343^{\star \star}$ & $195^{\star \star}$ \\
\hline & Önem Seviyesi & ,000 & ,000 &, 000 & 160 & ,000 & ,109 & ,000 & ,009 \\
\hline & $\mathrm{N}$ & 179 & 181 & 179 & 181 & 179 & 181 & 179 & 181 \\
\hline
\end{tabular}


Tablo 4'de öncelikle Kırgız öğrencilerin değerlendirmelerine bakıldığında, empatik eğilim ile 'İletişim ilkeleri ve temel beceriler' boyutları arasında 0.05 önem seviyesinde anlamlı ilişki bulunmaktadır. Korelasyon katsayısı 0,478'dir. Buna göre empatik eğilim ile 'İletişim ilkeleri ve temel beceriler' arasında pozitif yönlü orta derecede kuvvetli bir ilişkinin bulunduğu söylenebilir. Bir diğer boyut olan 'Kendini ifade etme' boyutu ile empatik eğilim arasında da 0.05 önem seviyesinde hesaplanan korelasyon katsayısı 0,320'dır. Buna göre empatik eğilim ile kendini ifade etme arasında pozitif yönlü zayıf derecede bir ilişkinin olduğu görülmektedir. İletişim becerileri boyutlarından 'Etkin dinleme ve sözel olmayan iletişim' ile empatik eğilim arasında hesaplanan korelasyon katsayısı 0,314'dır. Bu da bir önceki boyuta yakın pozitif yönlü zayıf ilişkiyi tanımlamaktadır. Tablo 4'de empatik eğilim ile 'İletişim kurmaya isteklilik' boyutu arasında 0.05 önem seviyesinde korelasyon katsayısı 0,343'dür. Bu durum da iki değişken arasında pozitif yönlü ancak zayıf derecede bir ilişkinin olduğunu göstermektedir.

Tablo 4'de Türk öğrenciler tarafından yapılan değerlendirmelere bakıldığında ise, empatik eğilim ile 'İletişim ilkeleri ve temel beceriler' boyutu arasında 0.05 önem seviyesinde anlamlı ilişki bulunmaktadır. Korelasyon katsayısı 0,299'dır. Buna göre empatik eğilim ile 'İletişim ilkeleri ve temel beceriler' arasında pozitif yönlü zayıf derecede bir ilişkinin bulunduğu söylenebilir. Bir diğer boyut olan 'Kendini ifade etme' boyutu ile empatik eğilim arasında 0.05 önem seviyesinde istatistiksel olarak anlamlı olmadığından değişkenler arasında ilişki bulunmamaktadır. İletişim becerileri boyutlarından 'Etkin dinleme ve sözel olmayan iletişim' ile empatik eğilim arasında da 0.05 önem seviyesinde istatistiksel olarak anlamlılık bulunmadığından değişkenler arasında ilişki bulunmamaktadır. Tablo 4'de empatik eğilim ile 'İletişim kurmaya isteklilik' boyutu arasında 0.05 önem seviyesinde korelasyon katsayısı 0,195'dir. Bu durum iki değişken arasında pozitif yönlü ancak çok zayıf derecede bir ilişkinin olduğunu göstermektedir.

Tablo 5: Öğrencilerin Empatik Eğilim ile İletişsim Becerileri Arasında Korelasyon Analizi

\begin{tabular}{|c|c|c|c|c|}
\hline & & & İletişim Becerileri & İletişim Becerileri \\
\hline & & & Kırgız & Türk \\
\hline & & Korelasyon Katsayısı &, $445^{\star \star}$ &, $234^{\star \star}$ \\
\hline Spearman's & Empatik & Önem Seviyesi & ,000 & ,002 \\
\hline & & $\mathrm{N}$ & 179 & 181 \\
\hline
\end{tabular}

Araștırmada öğrencilerin empatik eğilimleri ile 'İletişim becerileri' arasında bir ilişkinin olup olmadığına ilişkin bulgular Tablo 5'te yer almaktadır. Tabloda görüldüğü üzere gerek Kırgız gerekse Türk öğrencilerin empatik eğilime ilişin değişkenleri ile 'İletişim becerileri' değişkenleri arasında istatistiksel olarak önem seviyesi 0.05 'ten küçük çıkmıştır. Bu sonuç korelasyon katsayısının istatistiksel olarak "0" dan farkll, güvenilir olduğunu ifade etmektedir.

Öncelikle Kırgız öğrencilerin değerlendirme sonuçlarına bakıldığında, korelasyon katsayısı 0.445 çıkmıştır. Bu durum empatik eğilim ile 'İletişim becerileri' arasında pozitif yönlü orta derecede kuvvetli bir ilişkinin bulunduğunu ifade etmektedir. Başka bir anlatım ile bu bulgu Kırgız öğrencilerin empatik eğilimleri artıkça iletişim becerileri de artar sonucunu ortaya koymaktadır. Tablo 5'te Türk öğrencilerin değerlendirme sonucuna bakıldığında da korelasyon katsayısı 0.234 çıkmıştır. Bu 
durum da empatik eğilim ile iletişim becerileri arasında pozitif yönlü ancak kuvvetli olmayan bir ilişkinin bulunduğunu göstermektedir.

\section{Sonuç}

İlgili literatürde insanları anlama becerisi için kişilerarası algı, sosyal algı, sosyal duyarlılık ve empati gibi çeşitli kavramlar kullanılmaktadır. Yapılan sosyo-psikolojik araștırmalar sonrasında bugün empatinin de karşımızdaki insanları doğru anlamak ve doğru hissetmek anlamları taşıdığı görülmektedir. Dökmen'e göre (2004) de, anlamak empatik iletişimin bilişsel yönünü ifade ederken, hissetmek duygusal yönün göstergesi olmaktadır.

Geniş, farklı anlamsal çerçevede ele alınsa da empati kavramı, en yalın anlatımla 'doğru anlama ve algılama işlemi'dir. Burada 'doğru' ile kastedilen, anlamanın kaynaktaki kişinin paradigmasına göre değil de, karşıdaki empati kurulan kişinin paradigmasına göre gerçekleşebilmesidir. Olay ya da durumu konuşulan kişinin dünya görüşüne göre anlamaya çaba sarf etmek gerekmektedir.

Ancak ilgili literatüre dahil olmuş araştırmacıların benzer anlamsal yaklaşıma farklı adlandırmalarda bulundukları da gözlenmektedir. Sözgelimi, araștırmacıların çoğunluğu tarafından 'empati ve/veya empatik davranış' olarak adlandırılan kavramın, kişi algısı, sosyal duyarlılık, duygusal duyarlılık, rol alma, bakış açısı alma vb. çeşitlilikte ele alındığı da görülmektedir.

Araştırmada iletişim becerilerini inşa eden etkenler sorgulamasında empatik davranış temel çıktı olarak ele alınmıştır. Bu bağlamda elde edilen başat sonuçları değerlendirmeye almadan önce İletișim Fakültelerinin öğrencilerin iletişim becerilerini yetkinleștirmeye yönelik müfredat içeriği de incelenmiştir.

İletişim Fakülteleri'nde öğrencilerinin iletişimde etkili olmalarını sağlamak, sosyalizasyon süreci içinde edindikleri iletişim becerilerini daha etkin kılarak mesleki yetkinliğe ulaştırmak başat amaçlardan sayılmaktadır. Bu bağlamda İletişim Fakültelerinin ders programlarında yer alan iletişime giriş, örgütsel iletişim, yaratıcı drama, kamuoyu ve halkla ilişkiler gibi derslerin kapsamında kişilerarası iletişim ya da bireylerarası iletişim; yüz yüze iletişim ya da beden dili konu başlıklarına rastlanmaktadır. Bu içerikler genellikle bir yarıyıl ile sınırlandırılmış derslerin içerisinde yer almaktadır.

Linguistik, non-linguistik olmak üzere her boyutta öğrencilere iletişim becerileri kazandırmayı amaçlayan 'Kişilerarası iletişim' dersi İstanbul Üniversitesi İletişim Fakültesi programında yer almaktadır. Anadolu Üniversitesi İletişim Fakültesi programında 'Genel ve Teknik İletişim' adlı dersin içeriğinde kişilerarası iletişim, sözlü ve sözsüz iletişim olarak ikiye ayrılmakta ve 'dil, dinleme alışkanlığl, beden dili, klyafetler' ile ilişkilendirilmektedir. Hacettepe Üniversitesi İletişim Fakültesi'nde psikoloji, toplumsal psikoloji ve iletişim disiplini ile bağdaştırılmakta 'bireyin diğer kişilerle ilişki kurması, toplumsal yaşamını düzenlemesi' olarak tanımlanmaktadır. Daha çok sürtüşme ve çatışma çözme konuları kapsamında ele alınmaktadır. Kocaeli Üniversitesi İletişim Fakültesinde kişilerarası iletişim ders içeriği sözlü, sözsüz iletişim, beden dili, konuşma-dinleme becerileri, liderlik, motivasyon konularını içermektedir. 'Kişilerarası İletişim' dersi adının yerine 'İkna Edici İletişim' (Galatasaray Üniversitesi), 'Sunum Teknikleri' (Marmara Üniversitesi) 'Etkili Konuşma' ve ‘Bireylerarası İletișim’ (Akdeniz Üniversitesi) adlarının da tercih 
edildiği görülmektedir. İstanbul Ticaret Üniversitesi ve İzmir Ekonomi Üniversitesi İletişim Fakülteleri ise 'etkili iletişim, dil, sunum teknikleri, konuşma-dinleme becerisi' olarak kişilerarası iletişimden söz etmektedirler. Başkent Üniversitesi İletişim Fakültesi programında 'İletişim Bilimi' adıyla okutulan derste, 'sözel ve sözsüz iletişim becerisi kazandırma, iletişim çatışmaları ve çözüm yolları bulma' olarak tanımlanmaktadır.

Araştırmanın örneklemine dahil olan Kırgızistan-Türkiye Manas Üniversitesi İletişim Fakültesi programında da 'İletişim Bilimine Giriş', 'Örgütsel ve Kişilerarası İletişim', 'Sosyal Psikoloji', 'Etkili Yazılı ve Sözlü Anlatım Teknikleri', 'İkna Edici İletişim ve Retorik' dersleri yer almaktadır. Bu derslerde öğrencilerin iletişim becerilerini geliştirmek amacıyla sözlü ve yazılı iletişim, sözsüz iletişim, kişilerarası iletişim, etkileşim ve empati, iletişimde dinleme ile ilgili sorunlar, ikna edici iletişim vb. içerikler ayrıntılı aktarılmaktadır.

Araştırmanın örneklemi içinde yer alan bir diğer birim olarak, Erciyes Üniversitesi İletişim Fakültesi ders programında da yine öğrencilerin sosyal etkileșim ve iletişimde yetkinleşmelerini sağlayacak dersler bulunmaktadır. Bu amaçla 'İletişim Bilimine Giriș', 'Kişilerarası İletişim', 'Etkili ve Güzel Konuşma', 'Kültürel İletişim Çalışmaları', 'Sosyal Psikoloji', 'İletişim Sistemleri', Stratejik İletişim Yönetimi' ve 'Uluslararası İletişim' dersleri programa yerleştirilmiştir.

Bu derslerin öğrencilerin iletişim yetkinliklerine kazandırdıkları düşünüldüğünde iletişim becerileri ile empati eğilimleri arasındaki korelasyonun pozitif yönlü olması beklentisi yüksek olmuştur. Ancak elbette bu durum daha çok dört yıllık eğitim çıktısı olarak öngörülebilen sonuçlara bağlı olarak gerçekleşebileceği için bu ve benzeri araştırmaların mezunlarla da yinelenmesi önerilmektedir.

Araştırmanın örneklemine dahil olan öğrencilikleri devam etmekte olan katılımcıların da iletişim becerileri ile empati yatkınlıkları arasındaki ilişki pozitif yönlü elde edilmiştir. Araştırmaya katılan Kırgız öğrencilerin iletişim becerilerine ilişkin soruların genel ortalamaları 3.86 iken, Türk öğrencilerin 4.06 olarak bulgulanmıştır. Bu ortalamaları birbirlerine yakın, olumlu bir sonuç olarak değerlendirmek mümkündür.

Araştırmanın bir başka sorgulaması empatik eğilim üzerine gerçekleştirilmiş, Kırgız öğrencilerin empatik eğilimlere ait sorulara yaptıkları genel değerlendirmelerde 3.54 ortalamaya ulaşılırken, Türk öğrencilerin ortalaması ise 3.45 bulunmuştur. Katılımcı grupların empatik eğilimlerde de birbirlerine yakın sonuçlar verdikleri anlaşılmıştır.

Katılımcıların iletişim becerileri ile empatik eğilimlerine ilişkin korelasyon katsayıları araştırmanın temel çıktılarından birini oluşturmuştur. Kırgız öğrencilerin değerlendirme korelasyon katsayısı 0.445 olarak elde edilirken, Türk öğrencilerin korelasyon katsayısı 0.234 olarak bulgulanmıştır. Bu durum, Kırgız öğrencilerde 'empatik eğilim' ile 'İletişim becerileri' arasında pozitif yönlü orta derecede kuvvetli bir ilişkinin bulunduğunun göstergesi olarak değerlendirilmiştir; Türk öğrencilerde ise empatik eğilim ile iletişim becerileri arasında pozitif yönlü ancak kuvvetli olmayan bir ilişkinin bulunduğu sonucuna ulaştırmıştır. 
Genel olarak değerlendirmek gerekirse gerek Kırgız gerek ise Türk öğrencilerin 'iletişim becerileri' ve 'empatik eğilim' ortalamalarının olumlu yönde olmakla birlikte, bu iki yetkinlik durumları arasındaki korelasyon sonuçlarının çok yüksek düzeyde olmadığı görülmüştür. Söz konusu bu durumu yükseköğretimden önceki sosyolizasyon sürecine ilişkin kültürel aktarımlara dayandırmak olasıdır. Dolayısıyla, bireylerde empatik tutumu güçlendiren sosyal ve kültürel faktörlerin yetiştirilme süreçlerinde ediniminin gerek sosyal etkileşim gerekse sosyal iletişim açısından ne denli önem taşıdığı açıkça görülmektedir. $\mathrm{Bu}$ nedenle, iletişim yetkinliğinin ve sosyal duyarlılığın gelişiminin birincil ve ikincil sosyal çevrelerin kültürel kodlarına göre daha kapsamlı süreçlerde araştırılması oldukça önemli olarak bulgulanmıştır. Bu türden araştırmaların, belirtilen süreç kesitlerinde periyodik olarak yinelenmesi gerekliliği de önerilmektedir.

\section{Kaynakça}

Akgün, R. ve Çetin, H. (2018). “Üniversite Öğrencilerinin İletişim Becerilerinin ve Empati

Düzeylerinin Belirlenmesi", Manas Sosyal Araştırmalar Dergisi, Cilt 7, Sayı 3, 103117.

Akıncı, Z. B. (1998). Kurum Kültürü ve Örgütsel İletişim, İstanbul, İletisim Yayınları.

Akkoyun, F.(1982). “Empatik Anlayıș Üzerine”, Ankara Üniversitesi Eğitim Bilimleri

Fakültesi Dergisi, 15 (2), 64-69

Akkoyun, F. (1983). “Empatik Olmak, Değeri Anlaşılmamış Bir Varoluş Şeklidir”, Çev., Rogers C. R., Empathic: An Unappreciated Way of Being The Counseling Psychologist, 5 (2), Ankara Üniversitesi Eğitim Bilimleri Fakültesi Dergisi, 16, 103-124

Allport, W. (1967). "Attitudes", Readings in Attitude Theory and Measurement, Ed. Martin Fishbein, New York, John Wiley and Sons, Inc.

Altıntaş, E. ve Çamur, D. (2001). Sözsüz iletişim ve Beden Dili, Ankara, Nobel Yayıncılık. Altunışı, İ. (2008). Tüketici Davranışları, İstanbul, Beta Yayınları.

Apaydın Demirci, Z. ve İkiz, S. (2017). "Çocuk gelişimi Öğrencilerinin İletișim Becerileri ve Empatik Eğilim Düzeyleri Arasındaki İlişki: Bilecek Şeyh Edebali Üniversitesi Örneği”, Uluslararası Sosyal Araştırmalar Dergisi, Cilt 10, Sayı 54, 678-685.

Arkonaç S. (1993). Grup İlişskileri, İstanbul, Alfa Yayınları.

Atabek N, ve Dağdaş E. (1998). Kamuoyu ve İletişim, Eskişehir, Anadolu Ünivesitesi Yayınları.

Aziz A. (2008). İletişime Giriş, Aksu Yayınları, İstanbul.

Babadoğan C.(1992) "Hümanistik Eğitim Ve Öğretim Anlayıș”, Ankara Üniversitesi Eğitim Bilimleri Fakültesi Dergisi, 25(2):743-753

Baltas, Z. ve Baltas, A. (2001). Bedenin Dili, İstanbul, Remzi Kitabevi.

Balcı, Ali. (2009). Sosyal Bilimlerde Araştırma: Yöntem, Teknik ve İlkeler, Ankara, Pegem Akademi Yayınları 
Başaran İ.E. (1997). Yönetimde İnsan İlişsileri ve Yönetsel Davranış, Gül Yayınevi, Ankara.

Baysal, A. (1981). Sosyal ve Örgütsel Psikolojide Tutumlar, İstanbul, Sistem Yayıncılık.

Beștav, G. (2009). Psikoterapi, www.psikohipnoz.com/psikoterapi. html/5 Ocak 2009

Bıçakçı İ. (1998). Halkla İlişkiler ve İletişim, Ankara, Mediacat Yayınları.

Bülbül, A. R. (2000). Uluslararası İletişim, Konya, Damla Ofset.

Cooper, R.K ve Sawaf, A. (2000). Liderlikte Duygusal Zeka (Yönetimde Ve Organizasyonda Duygusal Zeka), Sistem Yayıncılık, İstanbul.

Cüceloğlu, D. (2000). İyi Düşün Doğru Karar Ver, İstanbul, Sistem Yayıncılık.

Cüceloğlu, D. (2000). Yeniden İnsan İnsana, 24. Baskı, Remzi Kitabevi, İstanbul.

Çoşar, U. Ö. (2010). “Kayseri Eğitim ve Araştırma Hastanesi'nde Çalışan Personellerin İletişim Kurma Becerilerinin Değerlendirilmesi”, Erciyes Üniversitesi Eğitim Bilimleri Enstitüsü Eğitim Bilimleri Bilim Dalı Yayımlanmamış Y. L. Tezi, 108ss

Davis K. (1998). İşletmede İnsan Davranışı, Çev., K.Turan, Bilim ve Sanat Basımevi, Ankara.

Davis, C. M. (2005). “Empati Nedir, Empati Öğretilebilir mi?” Çev., Ö. Sezer ve S. Damar, İnönü Üniversitesi Eğitim Fakültesi Dergisi, 6 (9), 77-88.

De Vito, J. A. (1998). The interpersonal Communication Book, 8. Baskl, United States. Çev., Vural, S. (2002) Kişilerarası İletişim, Kırgızistan-Türkiye Manas Üniversitesi Yayınları, 27.

Demiray U. (1994). İletişim Ötesi İletişim, Eskişehir, Turkuaz Yayınları.

Dilekman, M. Başcl, Z ve Bektaş, F. (2008). “Eğitim Fakültesi Öğrencilerinin İletişim Becerileri”, Atatürk Üniversitesi Sosyal Bilimler Enstitüsü Dergisi, 12(2):223231.

Dökmen, Ü. (1998). “Empatinin Yeni Bir Modele Dayanılarak Ölçülmesi ve Psikodrama ile Geliştirilmesi”, Ankara Üniversitesi Eğitim Bilimleri Dergisi, 21(1-2):155190.

Dökmen, Ü. (2004). İletişim Çatışmaları ve Empati, 26. Baskı, Mayıs, Sistem Yayıncılık. Dönmezer, S. (1990). Sosyoloji, İstanbul, Beta Yayınları.

Duverger, M. (1971). Politika Bilimine Giriş, Çev., Samih Tiryakioğlu, İstanbul, Varlık Yayınları.

Erdem F, ve Özen J. (2003). “Niklas Luhmann'ın Tanıdıklık, Emin Olma ve Güven Ayrımı", Sosyal Bilimlerde Güven, Ankara, Vadi Yayınları.

Erdem F. (2003). “Örgütsel Yaşamda Güven”, Sosyal Bilimlerde Güven, Ankara, Vadi Yayınları.

Erdoğan, İ. (2005). İletişimi Anlamak, İstanbul, Erk Yayınları.

Erigüç, G., Şener, T. ve Eriş, H. (2013). “İletişim Becerilerinin Değerlendirilmesi: Bir Meslek Yüksekokulu Öğrencileri Örneği”, Hacettepe Sağlık İdaresi Dergisi, Cilt 16, Sayı 1. 
Eroğlu, F. (2000). Davranış Bilimleri, İstanbul, Beta Basım Yayınları.

Ersanlı, K. \& Balcı, S. (1998). “İletişim Becerileri Envanterinin Geliştirilmesi: Geçerlik ve Güvenirlik Çalışması”, Türk Psikolojik Danışma ve Rehberlik Dergisi, 10 (2), 7-12

Ertürk, Y. D. (2007). “ İletişim Tarzı ve Benlik Oluşumunda, Duygusal Zeka Etkeni: İletişim Fakültesi Öğrencileri Üzerine Bir İnceleme”, Uluslararası Duygusal Zeka ve İletişim Sempozyumu Bildiri Kitabı, (1), 453-475, İzmir, 7-9 Mayıs

Fiske, J. (1996). İletişim Çalışmalarına Giriş, Çev. S. İrvan, Ankara, Bilim Sanat Yayınları.

Frankel, J. R. ve Wallen N.E. (2003). How to design and evaluate research in education, New York, McGraw Hill.Freeman J.L, Sears D., Carlsmith J.M. (1998). Sosyal Psikoloji, Çev., Ali Dönmez, Ankara, İmge Kitabevi.

Geçtan E. (1986). Insan Olmak / Varoluşun Bireysel ve Toplumsal Anlamı, İstanbul, Adam Yayınları.

Goffman, E. (1973). Presentation of Self in Everyday Life, New York, The Overlook Press.

Goleman, D. (1995). Duygusal Zeka: Neden IQ'dan daha önemlidir?, İstanbul, Varlık Yayınları.

Gordon, T. (1997). Etkili Anababa Eğitim, Çev., Aksay E., İstanbul, Sistem Yayıncılık.

Gordon, T. (1998). E.S.E. Etkili Liderlik Eğitim, İstanbul, Sistem Yayıncılık.

Gökçe, O. (1998). İletişim Bilimine Giriş, Ankara, Turhan Kitabevi.

Gökırmak M. (2003). "Küresel Kriz ve Politikada Güven”, Sosyal Bilimlerde Güven, Ed., Ferda Erdem, Ankara, Vadi Yayınları.

Güllübahçe, Ö. (2010). "K.K. Eğitim Fakültesi Öğrencilerinin İletişim Becerilerinin İncelenmesi", Atabesbd, 12(2), 12-22.

Güney, S, (2006). Davranış Bilimleri, Nobel Yayınları.

Gürüz D., Eğinli A. (2008). İletişim Becerileri:Anlamak, Anlatmak, Anlaşmak, Nobel Yayınevi, Ankara

Hartley P. (1993). Interpersonel Communication, New York, Routledge.

Hortaçsu N. (1997). İnsan İlişkileri, İstanbul, İmge Kitapevi.

Hummet M. L., Wiemann J., Nussbaum J. (1994). Interpersonal Communication in Older Adulthood, London, Sage Publication.

İkiz, E. (2006). "Danışma Becerileri Eğitiminin Danışmanların Empatik Eğilim, Empatik Beceri ve Tükenmişlik Düzeyleri Üzerindeki Etkisi”, Dokuz Eylül Üniversitesi Eğitim Bilimleri Anabilim Dalı Yayımlanmamış Doktora Tezi, 191ss.

İnam A. (2003). "Her şeyin Başı Güven”, Sosyal Bilimlerde Güven, Ed. Ferda Erdem, Ankara, Vadi Yayınları.

İnceoglu, M. (2000). Tutum-Algı-İletişim, Ankara, İmaj Yayıncılık.

İsen G. ve Batmaz V. (2002). Ben ve Toplum, Ankara, Om Yayınevi. 
Kağıtçıbaşı Ç. (1999). Yeni İnsan ve İnsanlar, İstanbul, Evrim Yayınevi Yayınları, 10.Basim

Kalaycı, Şeref vd. (2006). SPPS Uygulamalı Çok Değişkenli İstatistik Teknikleri, Ankara, Asil Yayınları

Kalkan, A. (2011). "Kișisel Tutum, Öznel Norm ve Algılanan Davranıș Kontrolünün Girișimcilik Niyeti Üzerindeki Etkisi: Üniversite Öğrencileri Üzerine Bir Uygulama", Süleyman Demirel Üniversitesi Sosyal Bilimler Enstitüsü Dergisi, 2, $14,189-206$

Karaman T. (2003). "Grup Psikoterapisi Bağlamında Güvenin Gelişimi", Sosyal Bilimlerde Güven, Ed., Ferda Erdem, Ankara, Vadi Yayınları.

Kartari A. (1999). "Kültürlerarası İletişim ve Bir Araştırma Projesi", Çukurova Üniversitesi Türkoloji Araştırmaları Merkezi, Folklor/Edebiyat, 19-26

Kayaalp, İ. (2002). İletişimde İnsan Dili, İstanbul, Bilge Kültür Sanat.

Korkut F. (1996). "İletişim Becerilerini Değerlendirme Ölçeğinin Geliştirilmesi: Güvenirlik ve Geçerlik Çalışmaları", Psikolojik Danışma ve Rehberlik Dergisi, 2(7),18-23.

Korkut F. (1999). “Üniversite Öğrencilerinin İletişim Becerilerinin Değerlendirilmesi”, 4. Ulusal Eğitim Bilimleri Kongresi Bildirileri, Anadolu Üniversitesi Yayınları, No. 1076, 208-218, Eskişehir.

Korkut, F. (2005). "Yetişkinlere Yönelik İletişim Becerileri Eğitimi”, Hacettepe Üniversitesi Eğitim Fakültesi Dergisi, 28, 143-149

Korkut Owen, T. ve Burgay, A. (2014). “İletişim Becerileri Ölçeği’nin Geliştirilmesi: Geçerlik ve Güvenilirlik Çalışması”, Mersin Üniversitesi Eğitim Fakültesi Dergisi, Cilt 10, Sayı 2.

Köknal Ö. (1997). İnsanı Anlamak, İstanbul, Altın Kitaplar Yayınevi.

Köknal Ö. (1998). Korkular, Takıntılar Saplantılar, İstanbul, Altın Kitaplar.

Kuran T. (2001). Yalanla Yaşamak/Tercih Çarpıtmasının Toplumsal Sonuçları, Çev., Alp Tümertekin, İstanbul, Yapı Kredi Yayınları.

LaFolilette H. (1999). Kişisel İlişsiler, Çev: Ferma Lekesizalın, İstanbul, Ayrıntı Yayınları.

Luft, J. (1984). Group Processes, Palo Alto, CA, Mayfield Publishing.

Mcshane, S.L. ve Glinow, M.A.V. (2000). Organizational Bahavior, New York, McGraw Hill.

Mete, S. ve Gerçek E. (2005). "PDÖ Yöntemiyle Eğitim Gören Hemşirelik Öğrencilerinin Empatik Eğilim ve Becerilerinin İncelenmesi”. C.Ü. Hemşirelik Yüksek Okulu Dergisi, Cilt: 9(2):11-17

Morgan, C. (1980). Psikolojiye Giriş, Ankara, Meteksan

Mutlu E. (1994). İletişim Sözlüğü, Bilim Sanat Yayınları, Ankara.

Navaro L. (2000). Gerçekten Beni Duyuyor musun? Remzi Yayınevi, İstanbul.

Neuman, W.L. (2009). Toplumsal Araștırma Yöntemleri: Nitel ve Nicel Yaklaşımlar, (Çev. Sedef Özge), İstanbul: Yayınodası Yayınları 
Noelle-Neumann E. (1998). Kamuoyu, Suskunluk Sarmalının Keşfi, Çev., Murat Özkök, Ankara, Dost Kitabevi.

Oskay Ü. (1994). İletişimin ABC'si, İstanbul, Simavi Yayıncılık.

Özcan M. T. (1998). İlkel Toplumlarda Toplumsal Kontrol, İstanbul, Özne Yayınları.

Özer, K. (1995). İletişimsizlik Becerisi, İstanbul, Varlık Yayınları.

Özodaşık M. (2009). Kişilerarası İletişim Sürecinde Algı-İkna ve Empatik İlişkiler, Tablet Yayınları, Konya.

Sabuncuoğlu Z. (1998). Örgütsel Yönetim, Ezgi Kitabevi Yayınları, Bursa.

Sakallı N. (2001). Sosyal Etkiler, İstanbul, İmge Kitabevi.

Schultz D.P., Schultz S.E. (2007). Modern Psikoloji Tarihi, Çev., Yasemin Aslay, Kaknüs Yayınları, İstanbul.

Şerif M. ve Şerif C. (1996). Sosyal Psikolojiye Giriş I - II, Çev., Mustafa Atakay, Aysun Yavuz, İstanbul, Sosyal Yayınları.

Timothy C. E., "Social Trust and Confidence", http://www.trustnetgovernance.com/, 10.07.2003

Usluata A. (1991). İletişim, İletişim Yayınları, İstanbul.

Usluata A. (1994). İletişim, İstanbul, İletişim Yayınları.

Ünal, C. (1972). "İnsanları Anlama Kabiliyeti”, Ankara Üniversitesi Eğitim Bilimleri Fakültesi Dergisi, 3(4), 71-93.

Yılmaz, B. (2007). "Üniversite Öğrencilerinin Kişilerarası İletişim Becerileri ve Bağlanma Stilleri Arasındaki İlişki”, Yüksek Lisans Tezi, Muğla Üniversitesi Sosyal Bilimler Enstitüsü.

Yılmaz, M. Üstün, A. ve Odacı, H. (2009). “Okul Öncesi Öğretmen Adaylarının İletişim Becerileri Düzeylerinin Çeșitli Değișkenlere Göre İncelenmesi”, Giresun Üniversitesi Sosyal Bilimler Enstitüsü Karadeniz Sosyal Bilimler Dergisi. 1(1):819.

Yüksel, A. H. (1994). Bireylerarası İletişime Giriş, Eskişehir, Açıköğretim Fakültesi Yayınları

Yüncü, F. (1995). Kişilerarası İlişkiler, Ankara, Yüncü Yayınları.

Zıllıglu, M. (1993). İletişim Nedir, İstanbul, Cem Yayınevi. 
